\title{
Curcumin and Photobiomodulation in Chronic Viral Hepatitis and Hepatocellular Carcinoma
}

\author{
Laura Marinela Ailioaie ${ }^{1,2}$ (1) and Gerhard Litscher ${ }^{3, *}$ \\ 1 Department of Medical Physics, Alexandru Ioan Cuza University, 11 Carol I Boulevard, 700506 Iasi, \\ Romania; lauraailioaie@yahoo.com \\ 2 Ultramedical \& Laser Clinic, 83 Arcu Street, 700135 Iasi, Romania \\ 3 Research Unit of Biomedical Engineering in Anesthesia and Intensive Care Medicine, Research Unit for \\ Complementary and Integrative Laser Medicine, and Traditional Chinese Medicine (TCM) Research Center \\ Graz, Medical University of Graz, Auenbruggerplatz 39, 8036 Graz, Austria \\ * Correspondence: gerhard.litscher@medunigraz.at; Tel.: +43-316-385-83907
}

Received: 8 September 2020; Accepted: 26 September 2020; Published: 28 September 2020

check for updates

\begin{abstract}
Immune modulation is a very modern medical field for targeting viral infections. In the race to develop the best immune modulator against viruses, curcumin, as a natural product, is inexpensive, without side effects, and can stimulate very well certain areas of the human immune system. As a bright yellow component of turmeric spice, curcumin has been the subject of thousands of scientific and clinical studies in recent decades to prove its powerful antioxidant properties and anticancer effects. Curcumin has been shown to influence inter- and intracellular signaling pathways, with direct effects on gene expression of the antioxidant proteins and those that regulate the immunity. Experimental studies have shown that curcumin modulates several enzyme systems, reduces nitrosative stress, increases the antioxidant capacity, and decreases the lipid peroxidation, protecting against fatty liver pathogenesis and fibrotic changes. Hepatitis B virus (HBV) affects millions of people worldwide, having sometimes a dramatic evolution to chronic aggressive infection, cirrhosis, and hepatocellular carcinoma. All up-to-date treatments are limited, there is still a gap in the scientific knowledge, and a sterilization cure may not yet be possible with the removal of both covalently closed circular DNA (cccDNA) and the embedded HBV DNA. With a maximum light absorption at $420 \mathrm{~nm}$, the cytotoxicity of curcumin as photosensitizer could be expanded by the intravenous blue laser blood irradiation (IVBLBI) or photobiomodulation in patients with chronic hepatitis B infection, Hepatitis B e-antigen (HBeAg)-positive, noncirrhotic, but nonresponsive to classical therapy. Photobiomodulation increases DNA repair by the biosynthesis of complex molecules with antioxidant properties, the outset of repairing enzyme systems and new phospholipids for regenerating the cell membranes. UltraBioavailable Curcumin and blue laser photobiomodulation could suppress the virus and control better the disease by reducing inflammation/fibrosis and stopping the progression of chronic hepatitis, reversing fibrosis, and diminishing the progression of cirrhosis, and decreasing the incidence of hepatocellular carcinoma. Photodynamic therapy with blue light and curcumin opens new avenues for the effective prevention and cure of chronic liver infections and hepatocellular carcinoma. Blue laser light and UltraBioavailable Curcumin could be a new valuable alternative for medical applications in chronic B viral hepatitis and hepatocarcinoma, saving millions of lives.
\end{abstract}

Keywords: blue laser; hepatitis B; hepatocellular carcinoma; laser blood irradiation; photodynamic therapy; ultrabioavailability 


\section{Photobiomodulation and Regenerative Medicine}

The fascination of regenerative medicine is much stronger today when we are trying more than ever to reverse aging and to trigger the restoration of normal cell, tissue, and organ functions by regeneration, replacement, and repair [1].

Since their invention, low-level lasers (from red to near infrared), or more recently named photobiomodulation, applied in medicine proved to have beneficial effects on relieving pain, decreasing swelling and inflammation, and stimulating the healing of the living tissues, when used in appropriate doses.

More than 50 years after their first medical application, the biologically accepted effects of lasers are on cytochrome c oxidase in the mitochondria, increasing ATP production; modulating reactive oxygen species, nitric oxide, and the calcium ion levels; activating a multitude of transcription factors; improving the cellular metabolism; and increasing the synthesis of new proteins and cell proliferation and migration [2].

Nowadays, lasers and molecular medicine considering tissue repair in infectious diseases and cancers are inventions that gain control of our imagination in the attempt to defy illness and death [1].

Important advances in our understanding of the basic science of lasers' high-tech applications and photobiomodulation are constantly influencing the development of laser technology and the use of it. Translation of preclinical regenerative medicine into advanced therapy combined with nanotechnologies and natural products will lead to future developments, which protect the patients, reduce healthcare costs. and offer huge potential benefits.

Understanding and explaining all known photobiomodulation effects optimize future methods and extremely increase the effectiveness of low-level laser therapy as a modern approach in the treatment of chronic infections or inflammatory processes.

Numerous associated and combined photobiomodulation techniques were developed and are widely used nowadays: Locally, on the projection of internal organs; laser acupuncture; intracavitary, transdermal, and intravenous laser blood illumination; magnetic-laser therapy; laser phoresis; etc. [3].

\section{Chronic Hepatitis B Infection}

Hepatitis B is a DNA virus that infects liver cells and can cause both acute and chronic disease. Hepatic infection is one of the main causes of cirrhosis, hepatic decompensation, and hepatocellular carcinoma and, even in this third millennium of modern medicine, there are no satisfactory therapies for chronic hepatitis B virus. Both viral and host factors are responsible for determining whether the infection is cleared or becomes chronic. It is estimated that over 250 million people worldwide are positive for the surface antigen of hepatitis B, HBsAg [4].

In May 2016, the World Health Assembly endorsed the Global Health Sector Strategy (GHSS) on viral hepatitis 2016-2021. The GHSS calls for the elimination of viral hepatitis as a public health threat by 2030 , reducing new infections by $90 \%$ and mortality by $65 \%$ [4].

Chronic liver disease is responsible for millions of deaths annually and is characterized by permanent inflammatory processes that predispose to liver cancer and hepatocellular carcinoma. In healthy liver, inflammatory processes stimulate growth and repair and restore normal liver architecture. However, if liver inflammation becomes chronic, the balance of damage versus regeneration in the liver is disrupted and can lead to the formation of excessive scar tissue (fibrosis) [5].

In the long term, an exacerbation of fibrosis will lead to cirrhosis, which is characterized by abnormal liver architecture and function and is associated with a significant reduction in overall health and well-being. At cirrhotic stages, liver damage is often irreversible or difficult to treat. Cirrhosis leads frequently to death from liver failure or to hepatocellular carcinoma (HCC). Indeed, HCC is the first cause of death in cirrhotic patients [6] and is a tumor with poor prognosis, ranking third in terms of death by cancer. Furthermore, it is the fifth most prevalent cancer worldwide, with 800,000 new cases per year in the world $[7,8]$. 
In some European countries, like Romania, for example, according with the last studies, the prevalence of chronic hepatitis B (HBV) infection is extremely high. There are almost 1.3 million people with chronic $B$ virus infection and over 600,000 patients are infected with $\mathrm{HCV}$ (hepatitis C). Hepatitis $C$ interferon treatment is a past option and the emergence of new drugs opens the perspective of healing without side effects [9].

Currently, there are two therapeutic options for chronic hepatitis B, interferon (IFN) and analog nucleotides (NA). Treatment with interferon should be used with caution in patients with cirrhosis and is contraindicated in case of liver decompensation. Analogous nucleotides are generally well tolerated but have a high risk of developing resistance to them [10].

Therapeutic protocols proposed and used to date have shown that complete elimination of hepatitis B virus (with covalently closed circular DNA (cccDNA)) was not possible due to the resistance to the pharmacological medication used (for example: Lamivudine $70 \%$ resistance at five years, Adefovir 30\% resistance at five years) [11].

The main objectives of current treatments are suppressing the virus and controlling the disease by: Reducing inflammation/fibrosis and stopping the progression of chronic hepatitis, reversing fibrosis and diminishing the progression of cirrhosis, decreasing the incidence of hepatocellular carcinoma, which is not yet eliminated.

All up-to-date treatments are limited. There is still a gap in the scientific knowledge and a sterilization cure may not yet be possible with the removal of both covalently closed circular DNA (cccDNA) and the embedded HBV DNA.

First theoretical estimations of nucleotide action on blocking the formation of new cccDNA in a patient with chronic hepatitis B predicted that it would take approximately 14 years to eliminate intrahepatic cccDNA. Today we know for sure that nucleotides do not fully stop HBV replication or cccDNA formation [12].

A functional cure is currently achievable in a small percentage $(<10 \%)$ of patients after IFN or NA therapy. Future strategies should implement new targets and novel immunomodulatory therapies to restore both innate and adaptive immune responses in order to achieve HBsAg loss in a higher percentage ( $>50 \%$ ) of patients after completion of a limited course ( $\geq 2$ years) of treatment. However, special attention should be paid to uncontrolled immune activation that could lead to fatal hepatitis or extrahepatic organ damage [13].

\section{Antiviral Properties of Curcumin and Applications}

Antibacterial, antiviral, and anti-inflammatory properties of curcumin as a highly polyphenolic molecule were discovered many years ago and, since then, its strong antioxidative, antiproliferative, and apoptosis-promoting effects have been studied in many different cells. Safe and well tolerated even at higher doses, curcumin has been used for treating hyperproliferative diseases [14].

Current concerns about hepatitis B therapy include the discovery of new management methods to ensure easy, safe, and low-cost administration for curative and eradicative treatment that effectively and early controls viral replication without developing resistance.

There are studies that have demonstrated the valuable pharmacological impact of curcumin in hepatitis B [15], diabetic microangiopathy, immune-mediated inflammatory diseases, and even cancer [16]. 
New patented curcumin supplements with a bioavailability of 15,000 times higher offer the chance of increased efficiency on the natural product [17], which is unstable at physiological $\mathrm{pH}$ and has a low water solubility and a fast metabolism [16,17].

Experimental studies have highlighted the potential of curcumin as an antiviral agent by downregulating cccDNA-bound histone acetylation, thereby inhibiting HBV gene replication [18].

Very recently, it has been shown that phytosomal curcumin with higher bioavailability blocks the formation of HCC, improves hepatic histopathology, reduces lipid accumulation and leukocyte infiltration, and diminishes total tumor volume in transgenic mice. Thus, there is a chance of HCC chemoprevention in chronic HBV infection [19].

With a maximum light absorption at $420 \mathrm{~nm}$ [20], the cytotoxicity of curcumin as photosensitizer could be expanded by the intravenous blue laser blood irradiation (IVBLBI) [17].

It has been shown in several scientific studies that the blue part of the visible spectrum (400-500 nm) is responsible for the suppression of various pathogens [21-24].

One hypothesis would be an overload of harmful reducing equivalents throughout the respiratory chain complexes and an extra production of reactive oxygen species (ROS) under blue light irradiation [21].

Several studies have shown that ultrashort laser pulses are capable of inactivating different viruses [25-29].

The mechanism of action initially proposed was that laser radiation produces high frequency resonance vibrations, with a bandwidth of $420-430 \mathrm{~nm}$, capable of destroying the virus capsid by nonthermal treatments, within a few hours [30].

Kingsley et al. proved that the action of the low-power blue laser generates singlet oxygen and, thus, inactivation of viruses occurs through a photochemical mechanism [31].

It is widely known that photobiomodulation is a highly effective method for treating patients with various diseases. Low-intensity (low-energy) laser light used today is safe and may even increase the effectiveness of biological agents in some unresponsive cases [32]. It does not have teratogenic, mutagenic, or carcinogenic properties [33] but, on the contrary, it ensures the protection of organisms against the most different pathogenic factors of biological, chemical, or physical nature, triggering the processes of repair and regeneration inside the living cells [17].

Laser irradiation enhances chromatin recovering, or damaged DNA repair; the biosynthesis of the antioxidant system; the initiation of repairing processes of enzymes (these begin to form, as well as various types of energy-rich substances begin to synthesize); the synthesis of phospholipids, forming cell membranes; the process of reparative regeneration; the proliferation of cellular systems; microcirculation; the biosynthesis of neurotransmitters; the sympathetic activity of the autonomic nervous system; the speed of nerve impulses and the intracardiac conduction; and the neurosecretion process $[33,34]$.

How to kill a virus with laser? Blue laser blood illumination should be preferably used for the correction of immune disorders of various etiologies and as an antimicrobial therapy. For example, in a recently published article by Zhu et al. it was proven by ex vivo and in vivo studies that antimicrobial blue light is a potential alternative or adjunctive therapeutic for infectious keratitis [35]. The mechanism of action of antimicrobial blue light is still not fully understood. A common hypothesis is that antimicrobial blue light excites the naturally occurring endogenous porphyrins or/and flavins in microbial cells and subsequently leads to the production of cytotoxic reactive oxygen species (ROS) [36]. Host-virus interactions in recent literature include the vital role played by host metabolism on viral replication and the proactive participation of mitochondria in this process. Different viruses use distinctive strategies to modulate mitochondrial bioenergetics and enhance viral replication. As a result, energy-yielding metabolic pathways are programmed to provide both energy and biosynthetic resources to drive viral protein synthesis and produce infectious particles. Therefore, metabolic antagonists may prove important not only to outline efficient therapy strategies but also to shed light on the pathogenesis of viral infections [37]. 
All pathophysiological mechanisms involved in deteriorating cellular function are also not clarified in detail. But it is confirmed that viruses are modulators of the mitochondrial functions, promoting changes in the mitochondrial bioenergetics and triggering an unbalanced mitochondrial metabolism. As a result, the alterations will be both ultrastructural (mitochondria swelling and other morphological changes typical for the apoptotic processes), as well as energetic: A decrease in ATP content and in the energy charge of virus-infected cells. These alterations in mitochondrial physiology and energy homeostasis will proceed cell death due to metabolic stress and the mitochondrial dysfunction and alterations in maintaining the cellular ATP balance.

In our studies, low-level laser therapy allows the consideration of photobiomodulation as an active therapeutic factor, potentiating the curcumin effect [17]. Curcumin features many of the attributes of an ideal photosensitizer for photokilling of pathogens: It is small, can form singlet oxygen in an aprotic environment, and features excellent biocompatibility [38]. UltraCur, a curcumin-whey complex with a 15,000-fold bioavailability and patented in the USA, has a bioavailability equal to $240,000 \mathrm{mg}$ standard curcumin and could be successfully used in connection with the blue laser for treating chronic infectious and age-related diseases [17].

In vitro studies have shown that curcumin can decrease monocyte chemoattractant/chemotactic protein-1 (MCP-1) production in various cell lines. Animal studies have also revealed that curcumin can attenuate MCP-1 expression and improve a range of inflammatory diseases through multiple molecular targets and mechanisms of action. MCP-1, a member of the CC chemokine family, is one of the key chemokines that regulate migration and tissue infiltration of monocytes/macrophages. Its role in the pathophysiology of several inflammatory diseases has been widely recognized, thus making MCP-1 a possible target for anti-inflammatory treatments. However, there is limited data from human clinical trials showing the decreasing effect of curcumin on MCP-1 concentrations and improvement of the course of inflammatory diseases [39].

Curcumin can also downregulate the expression of various proinflammatory cytokines including TNF, IL-1, IL-2, IL-6, IL-8, IL-12, and chemokines, most likely through inactivation of the transcription factor NF-kappa B (nuclear factor kappa-light-chain-enhancer of activated B cells). Together, these findings warrant further consideration of curcumin as a therapy for immune disorders [40]. In the last years, also other natural products, such as hypericin, riboflavin, etc., have been widely investigated as new photosensitizers [17].

Experimental and clinical studies have demonstrated a comprehensive range of remarkable biological effects (antiviral, antimicrobial, immunomodulatory, anti-inflammatory, antioxidant, antiproliferative, antiangiogenic, pro-apoptotic, and hepatoprotective) of curcumin on various cellular and molecular mechanisms (Table 1). 
Table 1. Molecular targets and protective effects of curcumin on pathogenic pathways [41-75]. $\boldsymbol{\nabla}=$ "decrease", $\mathbf{\Delta}=$ "increase".

\begin{tabular}{|c|c|c|c|}
\hline Biological Effects & References & $\begin{array}{c}\text { Molecular Targets/Pathogenic } \\
\text { Pathways }\end{array}$ & Conclusions \\
\hline \multirow{8}{*}{ Immunomodulator } & Yang, et al. [41] & $\begin{array}{l}\text { Reduces the receptor activator of } \\
\text { nuclear factor-kappa-B } \\
\text { ligand (RANKL) } \mathbf{v} \\
\text { Akt/NF-kB/NFATc1 pathways } \mathbf{\nabla}\end{array}$ & $\begin{array}{l}\text { Curcumin ameliorated the } \\
\text { RANKL-mediated differentiation, fusion } \\
\text { and maturation of osteoclasts and had an } \\
\text { immunomodulatory effect on macrophage } \\
\text { polarization; the protective effect of } \\
\text { curcumin on osteoclast genesis was } \\
\text { mediated by attenuating the up-regulation } \\
\text { of Akt and p65 phosphorylation and the } \\
\text { activation of the downstream transcription } \\
\text { factor NFATc1 (Nuclear Factor of Activated } \\
\text { T-cells, cytoplasmic } 1 \text { ). }\end{array}$ \\
\hline & Wu, et al. [42] & $\begin{array}{l}\text { NF- } \kappa \text { B, MAPK, Akt and } \\
\text { pBAD pathways } \mathbf{}\end{array}$ & $\begin{array}{l}\text { Curcumin treatment reduced activation of } \\
\text { the NF- } \mathrm{B}, \text { MAPK (mitogen-activated } \\
\text { protein kinase), Akt and pBAD } \\
\text { (systematically araBp, a promoter found in } \\
\text { bacteria) pathways either systemically, or } \\
\text { within the inflamed kidneys. These } \\
\text { findings suggest that natural food } \\
\text { supplements could become an alternative } \\
\text { approach to ameliorating } \\
\text { immune-mediated kidney diseases. }\end{array}$ \\
\hline & Tuyaerts, et al. [43] & $\begin{array}{l}\text { COX-2 expression in B cells, NK and } \\
\text { T cells. Myeloid -Derived } \\
\text { Suppressor Cell (MDSC): CD } 15^{+} \& \\
\text { CD } 33^{+} \text {granulocytic, and CD } 33^{+} \\
\text {monocytic. Expression of } \\
\text { HLA-DR/CD } 45^{+} \text {leukocytes }\end{array}$ & $\begin{array}{l}\text { It is observed a downregulation of MHC } \\
\text { expression by leukocytes, a reduction in the } \\
\text { frequency of monocytes and a decreased } \\
\text { inducible co-stimulator (ICOS) expression } \\
\text { by CD }{ }^{+} \text {T cells upon Curcumin } \\
\text { Phytosome (CP) intake, while the level of } \\
\text { CD69 on CD16- NK cells was upregulated; } \\
\text { did not find significant changes in } \\
\text { inflammatory biomarker levels, frequencies } \\
\text { of other immune cell types, T cell activation } \\
\text { and COX-2 expression. }\end{array}$ \\
\hline & Mollazadeh, et al. [44] & $\begin{array}{l}\text { Dendritic cells, macrophages, mast } \\
\text { cells, natural killer cells, eosinophils, } \\
\text { neutrophils, B cells, CD8+ T cells, } \\
\text { TH1, TH2, TH17 \& regulatory T cells }\end{array}$ & $\begin{array}{l}\text { Curcumin is a natural anti-inflammatory } \\
\text { compound able to induce the expression } \\
\text { and production of IL-10 and enhancing its } \\
\text { action on many tissues. }\end{array}$ \\
\hline & Boroumand, et al. [45] & $\begin{array}{c}\text { Neutrophils, macrophages, } \\
\text { monocytes, NK cells, dendritic cells } \\
\text { (DCs), T and B cells } \\
\text { Down regulating the expression of } \\
\text { growth and survival promoting } \\
\text { genes including c-Myc, BCL-XL } \\
\text { and NF-kB v }\end{array}$ & $\begin{array}{l}\text { This review discusses current knowledge } \\
\text { on the immunomodulatory, } \\
\text { anti-inflammatory and antioxidant roles of } \\
\text { curcumin, with the hope of recruiting } \\
\text { curcumin as a therapeutic agent in the } \\
\text { future therapeutic regimen. }\end{array}$ \\
\hline & Bai, et al. [46] & $\begin{array}{l}\text { Inhibition of nuclear factor-kappa } \\
\qquad \mathrm{B}(\mathrm{NF}-\mathrm{kB}) \boldsymbol{\nabla}\end{array}$ & $\begin{array}{l}\text { Curcumin is a potent inducer of } \\
\text { apoptosis-an effector mechanism used by } \\
\text { macrophages to kill intracellular } \\
\text { Mycobacterium tuberculosis (MTB). } \\
\text { Curcumin enhanced the clearance of MTB } \\
\text { in differentiated THP-1 human monocyte } \\
\text { and in primary human alveolar } \\
\text { macrophages. Curcumin was an inducer of } \\
\text { caspase-3-dependent apoptosis } \\
\text { and autophagy. }\end{array}$ \\
\hline & Antiga, et al. [47] & $\begin{array}{c}\text { Th22 cells, a subpopulation of } \\
\text { T cells } \mathbf{v}\end{array}$ & $\begin{array}{l}\text { In conclusion, curcumin was demonstrated } \\
\text { to be effective as an adjuvant therapy for } \\
\text { the treatment of psoriasis vulgaris and to } \\
\text { significantly reduce serum levels of IL-22. }\end{array}$ \\
\hline & Castro, et al. [48] & $\begin{array}{l}\text { NF-kB, iNOS } \\
\text { IL-6, TNF-alfa, } \\
\text { IL-1 beta } \mathbf{}\end{array}$ & $\begin{array}{l}\text { Curcumin modulates the T lymphocyte } \\
\text { response impairing proliferation and } \\
\text { interferon (IFN)- } \gamma \text { production through } \\
\text { modulation of T-box expressed in T cells } \\
\text { (T-bet), a key transcription factor for } \\
\text { proinflammatory T helper type } 1 \text { (Th1) } \\
\text { lymphocyte differentiation, both at the } \\
\text { transcriptional and translational levels. } \\
\text { Reduces nuclear factor (NF)-kB activation } \\
\text { in T cell receptor (TCR)-stimulated NOD } \\
\text { lymphocytes and secretion of } \\
\text { proinflammatory cytokines and nitric } \\
\text { oxide (NO). }\end{array}$ \\
\hline
\end{tabular}


Table 1. Cont.

\begin{tabular}{|c|c|c|c|}
\hline Biological Effects & References & $\begin{array}{c}\text { Molecular Targets/Pathogenic } \\
\text { Pathways }\end{array}$ & Conclusions \\
\hline \multirow{7}{*}{ Anti-inflammatory } & Lee, et al. [49] & $\begin{array}{c}\text { IFN- } \gamma, \text { TNF alfa, IL1 beta, } 6,10, \\
13.17 \mathbf{\nabla} \\
\text { NF-kB/COX-2 pathway and iNOS } \mathbf{v}\end{array}$ & $\begin{array}{l}\text { Authors conclude that } C \text {. longa and } A \text {. } \\
\text { hookeri co-treatment synergistically inhibit } \\
\text { inflammation by regulating the } \\
\text { NF-kB/COX-2/iNOS pathway. }\end{array}$ \\
\hline & Li, et al. [50] & $\begin{array}{c}\text { Macrophage (M); } \\
\text { Lipopolysaccharide (LPS), IFN- } \gamma \\
\text { promote M1-type macrophage; IL-4, } \\
10 \text { and IL-13 promote M2-type } \\
\text { macrophage polarization }\end{array}$ & $\begin{array}{l}\text { Macrophages play a pivotal role in } \\
\text { non-alcoholic fatty liver disease (NASH) } \\
\text { development. Evidence for natural } \\
\text { products or their active ingredients in the } \\
\text { modulation of macrophage activation, } \\
\text { recruitment, and polarization, as well as the } \\
\text { metabolic status of macrophages } \\
\text { were assessed. }\end{array}$ \\
\hline & Almatroodi, et al. [51] & $\begin{array}{c}\text { TNF- } \alpha, \text { IL- } 6 \mathbf{v} \\
\text { p53 expression } \mathbf{v} \\
\text { Glutathione peroxidase (GPx), } \\
\text { superoxide dismutase (SOD), } \\
\text { catalase (CAT) } \\
\text { Total Antioxidant } \\
\text { Capacity (TAC) } \% \Delta\end{array}$ & $\begin{array}{l}\text { Co-administration of curcumin }(50 \mathrm{mg} / \mathrm{kg} \text { ) } \\
\text { with } \mathrm{BaP}(50 \mathrm{mg} / \mathrm{kg} \text { ) exhibited significant } \\
\text { reduction in TNF- } \alpha \text { and the IL- } 6 \text { level; } \\
\text { significantly decreased the number of } \\
\text { TUNEL-positive cells. Curcumin plus BaP } \\
\text { decreased the p53 protein expression as } \\
\text { compared with the BaP group and intensity } \\
\text { of positivity was low as compared to the } \\
\mathrm{BaP} \text { only treated group. In addition, } \\
\text { curcumin administered to BaP induced rats } \\
\text { confirmed the improvement in SOD, CAT } \\
\text { and GPx, total antioxidant capacity, and } \\
\text { oxidative stress biomarker; significantly } \\
\text { decreased the accumulation of cells in the } \\
\text { G2/M phase and reduced the apoptotic cell } \\
\text { death level increased by BaP. }\end{array}$ \\
\hline & Vitali, et al. [52] & $\begin{array}{l}\text { IL-6, TNF- } \alpha \text { and MCP-1 } \\
\text { transcription factor NF- } \mathrm{kB} \text { v }\end{array}$ & $\begin{array}{l}\text { Results show that delivery of curcumin } \\
\text { nanoparticles directly into the vaginal tract } \\
\text { of mice infected with HSV-2 abrogated } \\
\text { CpG-oligodeoxynucleotide (ODN) induced } \\
\text { inflammatory vaginal pathology and } \\
\text { diminished the production of } \\
\text { pro-inflammatory cytokines IL- } 6 \text {, TNF- } \alpha \\
\text { and MCP-1 in vaginal and cervical tissues. }\end{array}$ \\
\hline & Ullah, et al. [53] & $\begin{array}{c}\text { Cycloxygenase-2 (COX-2) } \mathbf{v} \\
\text { Inhibitory kappa B Kinase (IKK) } \\
\text { and TANK binding kinase-1 (TBK-1) } \\
\text { of Toll Like Receptor } 4 \\
\text { (TLR4) pathway }\end{array}$ & $\begin{array}{l}\text { A continuous computerized examination of } \\
14 \text { compounds comprising curcumin, its } \\
\text { derivatives and analogues were } \\
\text { investigated as inhibitors of signaling } \\
\text { proteins: cyclooxygenase-2 (COX-2), } \\
\text { Kappa } \beta \text { kinase inhibitor (IKK) and TANK-1 } \\
\text { binding kinase (TBK-1), and Toll Path Like } \\
\text { Receptor } 4 \text { (TLR4) involved in } \\
\text { inflammation. This study recommends } \\
\text { 6-Gingerol, Yakuchinone A and } \\
\text { Yakuchinone B as the best inhibitors of } \\
\text { COX-2, IKK and TBK-1 respectively among } \\
\text { the selected curcumin analogues, which } \\
\text { could be considered as potential } \\
\text { anti-inflammatory agents in the search for } \\
\text { new medication against inflammation. }\end{array}$ \\
\hline & Shimizu, et al. [54] & $\begin{array}{c}\text { NF-kappa B } \\
\text { TNF-alpha, IL-1beta } \\
\text { myeloid differentiation protein } \\
\text { 2-Toll-like receptor } 4 \\
\text { co-receptor pathways } \mathbf{v} \\
\text { activates peroxisome } \\
\text { proliferator-activated } \\
\text { receptor-gamma (PPAR-gamma) }\end{array}$ & $\begin{array}{l}\text { A number of studies have reported the } \\
\text { efficacy of curcumin and the mechanisms by } \\
\text { which its anti-inflammatory activity could } \\
\text { treat various lifestyle-related conditions } \\
\text { associated with chronic inflammation, } \\
\text { including atherosclerosis, heart failure, } \\
\text { obesity, diabetes and other related diseases, } \\
\text { such as dementia. Most of these studies } \\
\text { have involved animal experiments; } \\
\text { however, there are several reports on the } \\
\text { benefits of curcumin use in humans. }\end{array}$ \\
\hline & Szebeni, et al. [55] & $\begin{array}{l}\text { human PBMCs (peripheral blood } \\
\text { mononuclear cells) } \\
\text { NF-kB; TNF-alfa, IL4, IL6 } \mathbf{v}\end{array}$ & $\begin{array}{l}\text { The effects of treatment with curcumin } \\
\text { analogues in the inflamed colon of rats } \\
\text { demonstrated a significant reduction in } \\
\text { total tissue myeloperoxidase (MPO) activity, } \\
\text { like the biological agent infliximab. } \\
\text { Mannich curcuminoids reported herein } \\
\text { possess a powerful } \\
\text { anti-inflammatory activity. }\end{array}$ \\
\hline
\end{tabular}


Table 1. Cont.

\begin{tabular}{|c|c|c|c|}
\hline Biological Effects & References & $\begin{array}{c}\text { Molecular Targets/Pathogenic } \\
\text { Pathways }\end{array}$ & Conclusions \\
\hline & Wal, et al. [56] & $\begin{array}{c}\text { NF- } \kappa B, \text { TNF- } \alpha \mathbf{v} \\
\text { COX-2, inducible nitric } \\
\text { oxide synthase } \\
\text { (INS) and lipoxygenase (COX). } \\
\text { INOs, LOX } \mathbf{v}\end{array}$ & $\begin{array}{l}\text { Curcumin has the potential for curing } \\
\text { inflammatory diseases as it blocks the } \\
\text { mechanism of reactive oxygen species } \\
\text { generation via inhibiting oxidative stress. } \\
\text { Curcumin has prominent effect on } \\
\text { inflammatory mediators like cytokines as a } \\
\text { result of which it blocks the oxidation } \\
\text { process in mitochondria of the cell and } \\
\text { reduces inflammation. }\end{array}$ \\
\hline & Chen, et al. [57] & $\begin{array}{c}\text { TNF- } \alpha, \text { IL- } 1 \beta \text { and IL- } 6 \text { as } \\
\text { pro-inflammatory cytokines } \mathbf{} \\
\text { NF- } \mathrm{kB} \text { p } 65 \text { v }\end{array}$ & $\begin{array}{l}\text { After four weeks of administration of } \\
\text { combined two natural products with } \\
\text { curcumin resulted in a decrease in the } \\
\text { inflammatory cell infiltration, less thickness } \\
\text { of the synovium and less volumetric } \\
\text { increase in the synovial space at } \\
\text { collagen-induced rat model arthritis; the } \\
\text { level of TNF- } \alpha \text {, IL-1 } \beta \text { and IL- } 6 \text { was } \\
\text { significantly decreased in serum. } \\
\text { Curcumin combination was able to inhibit } \\
\text { the expression of NF- } \mathrm{B} \text { p p65 and TNF- } \alpha \\
\text { which were closely related to the } \\
\text { inflammatory process. }\end{array}$ \\
\hline & Panahi, et al. [58] & $\begin{array}{c}\text { TNF-a, IL-6, TGF-b and MCP-1 } \mathbf{v} \\
\text { macrophages monocytes } \\
\text { NF-kBp65 }\end{array}$ & $\begin{array}{l}\text { Study suggests a significant decrease in } \\
\text { serum concentrations of TNF-a, IL-6, TGF-b } \\
\text { and chemoattractant protein-1 (MCP-1) } \\
\text { cytokines following curcumin } \\
\text { supplementation in subjects with } \\
\text { metabolic syndrome. }\end{array}$ \\
\hline \multirow[t]{2}{*}{ Antioxidant } & Paciello, et al. [59] & $\begin{array}{c}\text { Nuclear factor (erythroid-derived } \\
\text { 2)-like } 2 ») \text { or Nrf2/Heme } \\
\text { oxygenase-1 (HO-1) pathway; ROS } \\
\text { downregulating p53 } \\
\text { phosphorylation } \mathbf{~} \\
\text { NF-KB, STAT-3 } \mathbf{}\end{array}$ & $\begin{array}{l}\text { The authors used two different polyphenols } \\
\text { in adjuvant chemotherapy in several } \\
\text { malignancies to avoid the chemoresistance } \\
\text { and ototoxicity of the drug cisplatin. Both } \\
\text { polyphenols had an antioxidant and } \\
\text { self-protective action by up-regulating the } \\
\text { Nrf-2/HO-1 pathways and down-regulating } \\
\text { p53 phosphorylation; but only curcumin } \\
\text { has been able to influence the inflammatory } \\
\text { pathways that counteract NF- } \mathrm{B} \text { activation. } \\
\text { In human cancer cells, curcumin transforms } \\
\text { the antioxidant effect into a pro-oxidant and } \\
\text { anti-inflammatory one. Curcumin has } \\
\text { permissive and chemosensitive properties } \\
\text { by targeting chemoresistant factors of } \\
\text { cisplatin phosphorylation of Nrf-2, NF- } \mathrm{B} B \\
\text { and STAT-3. Therefore, polyphenols, } \\
\text { mainly curcumin, which target ROS } \\
\text { modulated pathways can be a promising } \\
\text { tool for the treatment of cancer. Due to their } \\
\text { biphasic antioxidant activity in normal cells } \\
\text { under stress and pro-oxidant in cancer cells, } \\
\text { these polyphenols are likely to involve an } \\
\text { interaction between key factors Nrf-2, } \\
\text { NF- } \mathrm{k} \text { B, STAT-3 and p53. }\end{array}$ \\
\hline & AlBasher, et al. [60] & $\begin{array}{c}\text { (MDA) malondialdehyde, }\{\mathrm{NO}\} \\
\text { nitric oxide } \mathbf{\nabla},\{\mathrm{GSH}\} \text { reduced } \\
\text { glutathione, }\{\mathrm{GPx}\} \text { glutathione } \\
\text { peroxidase, }\{\mathrm{SOD}\} \text { superoxide } \\
\text { dismutase, }\{\mathrm{CAT}\} \text { catalase } \boldsymbol{\Delta} \\
\text { Nrf2 ARE antioxidant response } \\
\text { elements }\end{array}$ & $\begin{array}{l}\text { This study was undertaken to assess the } \\
\text { effects of resveratrol (RSV) and curcumin } \\
\text { (CUR) on oxidative damage induced by } \\
\text { insecticide fipronil (FPN). Co-treatment } \\
\text { with RSV and CUR, mainly in combination, } \\
\text { markedly alleviated the toxic effects and } \\
\text { oxidative damage induced by FPN. Thus, } \\
\text { liver enzyme activities, renal injury } \\
\text { biomarkers, and lipid profiles in the sera, as } \\
\text { well as the MDA, NO, and GSH } \\
\text { concentrations and GPx, SOD, and CAT } \\
\text { activities (liver, kidney, and brain), were } \\
\text { normalized. RSV and CUR repaired } \\
\text { oxidative disorders through the Nrf2 } \\
\text { heterodimer that bound to antioxidant } \\
\text { response elements (AER) and regulated the } \\
\text { expression of antioxidant enzyme genes } \\
\text { such as GPx, SOD and CAT. }\end{array}$ \\
\hline
\end{tabular}


Table 1. Cont.

\begin{tabular}{|c|c|c|c|}
\hline Biological Effects & References & $\begin{array}{c}\text { Molecular Targets/Pathogenic } \\
\text { Pathways }\end{array}$ & Conclusions \\
\hline & Konak, et al. [61] & $\begin{array}{c}\text { SOD, CAT, GPx } \mathbf{\Delta} \\
\text { ROS, NO } \\
\text { total antioxidant capacity (TAC) } \\
\text { total oxidant capacity (TOC) }\end{array}$ & $\begin{array}{l}\text { Study investigated the antioxidant effect of } \\
\text { curcumin, a phytochemical, on the blood } \\
\text { tissue of rats. When the TAC and TOC } \\
\text { levels of curcumin-supplemented feeding } \\
\text { group were examined, the level was higher } \\
\text { than the control group }(\mathrm{P}<0.05) \text {. Results of } \\
\text { the study show that curcumin strengthens } \\
\text { the antioxidant defense system. }\end{array}$ \\
\hline & Nawab, et al. [62] & CAT, SOD, GSH-Px and T-AOC $\mathbf{v}$ & $\begin{array}{l}\text { The effects of increasing concentrations of } \\
\text { dietary curcumin on the antioxidant } \\
\text { parameters of layers maintained under } \\
\text { high-temperature conditions for nine weeks } \\
\text { were evaluated. Laying hens in all } \\
\text { curcumin treatment groups had slightly } \\
\text { higher activities of CAT, SOD, GSH-Px, and } \\
\text { T-AOC in the liver, heart, and lungs, } \\
\text { compared with heat stressed control group. } \\
\text { It was concluded that dietary curcumin } \\
\text { given to laying hens under heat stress may } \\
\text { enhance their antioxidant status and } \\
\text { alleviate the detrimental effects of stressful } \\
\text { environmental conditions. }\end{array}$ \\
\hline & Nawab, et al. [63] & $\begin{array}{c}\text { IL-6, IL-1 } \beta, \text { TNF- } \alpha, \mathbf{\nabla} \\
\text { TLR4, NF- } \mathrm{B} \text {; PCNA (proliferating } \\
\text { cell nuclear antigen) } \mathbf{v}\end{array}$ & $\begin{array}{l}\text { This study aimed to investigate the effect of } \\
\text { curcumin supplementation on TLR } 4 \\
\text { mediated non-specific immune response in } \\
\text { liver of laying hens under high-temperature } \\
\text { conditions and heat stress. Authors showed } \\
\text { that in the curcumin group treatment had } \\
\text { reduced inflammatory responses (IL-6, } \\
\text { IL-1 } \beta, \text { TNF- } \alpha \text { ) as compared to control } \\
\text { group. Furthermore, PCNA, TLR4 and its } \\
\text { downstream gene expression as well as } \\
\text { protein expression (TLR4, NF- } k B \text { and } \\
\text { PCNA) were significantly downregulated } \\
\text { in heat stress curcumin supplemented } \\
\text { group as compared to control. }\end{array}$ \\
\hline & Meshkibaf, et al. [64] & $\begin{array}{c}\text { Methionine Sulfoxide } \\
\text { Reductase A (MSRA) } \\
\text { SOD, CAT, GPx } \Delta\end{array}$ & $\begin{array}{l}\text { Effect of curcumin on arthritis induced by } \\
\text { adjuvant in rats, considering changes in } \\
\text { methionine sulfoxide reductase A (MSRA) } \\
\text { expression and antioxidant enzymes levels } \\
\text { were analyzed. Curcumin can be used } \\
\text { against inflammation. The increasing level } \\
\text { of MSRA can be due to the antioxidant } \\
\text { effect of curcumin. The enzymatic level } \\
\text { changes (MSRA, SOD, CAT and GPx) may } \\
\text { interfere with the aging process and } \\
\text { delay it. }\end{array}$ \\
\hline & Borra, et al. [65] & $\begin{array}{c}\text { MDA: Malondialdehyde, PC: } \\
\text { Protein carbonyls, GSH: Reduced } \\
\text { glutathione TAC: Total Antioxidant } \\
\text { Capacity } \mathbf{\Lambda} \text {; ROS } \mathbf{}\end{array}$ & $\begin{array}{l}\text { Curcumin has the ability to protect the } \\
\text { biomolecules like proteins, lipids and DNA } \\
\text { from hydroxyl radical oxidation. These } \\
\text { results demonstrate that exposure to OH in } \\
\text { serum and plasma is a good experimental } \\
\text { model for studying ROS-induced toxicity } \\
\text { and evaluating the protective effects of } \\
\text { various agents in vitro. }\end{array}$ \\
\hline & Jat, et al. [66] & $\begin{array}{c}\text { GSH॥ Lipid peroxidation }(\mathrm{LPO}) \mathbf{\nabla} \\
\text { Protein carbonyl } \mathbf{v} ; \mathrm{ROS} \mathbf{v}\end{array}$ & $\begin{array}{l}\text { This study shows the strong anti-oxidative } \\
\text { effects of curcumin and mitochondrially } \\
\text { targeted curcumin against the lipid } \\
\text { peroxidation, protein carbonylation and } \\
\text { mitochondrial permeability transition } \\
\text { induced by tert-butylhydroperoxide. Both } \\
\text { curcumin and mitochondrially targeted } \\
\text { curcumin significantly enhanced } \\
\text { endogenous reduced glutathione level in } \\
\text { the mitochondria thus preserving } \\
\text { mitochondrial defense system against } \\
\text { oxidative stress. }\end{array}$ \\
\hline
\end{tabular}


Table 1. Cont.

\begin{tabular}{|c|c|c|c|}
\hline Biological Effects & References & $\begin{array}{c}\text { Molecular Targets/Pathogenic } \\
\text { Pathways }\end{array}$ & Conclusions \\
\hline \multirow[b]{2}{*}{ Anti-angiogenic } & Norooznezhad, et al. [67] & $\begin{array}{c}\text { CD68+ and CD11b+ cells; IL-1, IL-6, } \\
\text { TNF- } \alpha, \text { VEGF } \boldsymbol{} \\
\text { hypoxia-inducible factor } 1 \alpha \\
(\text { HIF- } 1 \alpha)\end{array}$ & $\begin{array}{c}\text { Curcumin has a strong antioxidant } \\
\text { potential, can decrease oxidative stress and } \\
\text { it is able to inhibit the mentioned } \\
\text { inflammatory and angiogenic factors such } \\
\text { as IL-1, IL-6, TNF- } \alpha \text {, VEGF, MMPs, } \\
\text { and HIF- } 1 \alpha \text {. }\end{array}$ \\
\hline & Mohapatra, et al. [68] & $\begin{array}{c}\text { Glutathione (GSH) } \mathbf{v} \\
\text { Malondialdehyde (MDA) } \mathbf{} \\
\text { Superoxide dismutase (SOD) }\end{array}$ & $\begin{array}{l}\text { The combination of curcumin and ASA } \\
\text { (acetylsalicylic acid) significantly reduced } \\
\text { foot edema and the formation of } \\
\text { carrageenan-induced granuloma. } \\
\text { Concomitant use of curcumin with ASA } \\
\text { decreased malondialdehyde levels, while } \\
\text { relatively increased superoxide dismutase } \\
\text { and reduced glutathione, while proving } \\
\text { protection against (histologically) induced } \\
\text { hepatotoxicity by ASA. }\end{array}$ \\
\hline
\end{tabular}

Potent role of curcumin as epigenic modulator, influence on transcriptional factors, antioxidant effects, mediation of factors, antioxidant effects, mediation of
inflammatory cytokines and angiogenesis

p53 level

caspase activation $\Delta$

Hassan, et al. [69] tyrosine-regulated kinases (DYRKs) $\mathbf{v}$ $26 S$ proteasome activity $\mathbf{v}$ modulation was proved. Curcumin is a potent proteasome inhibitor that increases p53 level and induces apoptosis by mitochondrial caspase activation. Curcumin also disrupts 26S proteasome activity by inhibiting DYRK2 in different cancerous cells, resulting in the inhibition of cell proliferation.

Multiple in vitro and in vivo preclinical studies have shown that curcumin is

AMP-activated protein kinase NRF

Pro-Apoptotic /Antiproli-ferative (Nuclear Respiratory Factor 1);

Nuclear factor (erythroid-derived 2)like 2, also known as NFE2L2,

Mitochondrial transcription factor A (TFAM) TFEB (Transcription Factor EB)

Rainey, et al. [70] G2/M cell cycle

Peroxisome proliferator-activated receptor gamma coactivator 1-alpha $($ PGC $-1 \alpha)$-related signaling pathway. Activator protein 1 (AP-1), Caspase-10
Telomerase reverse transcriptase (TERT) ^; Malondialdehyde (MDA) $\mathbf{v}$

Guo, et al. [71] glutathione (GSH); superoxide $\mathbf{\Delta}$; dismutase (SOD) $\mathbf{4}$; glutathione peroxidase (GSH-Px); TNF- $\alpha$ and

IL- $1 \beta$ in the cerebral homogenates TERT mRNA expression level effective against various types of cancer.

These potent the effects are determined by the ability of curcumin to induce G2/M cell cycle arrest, induction of autophagy, activation of apoptosis, disruption of molecules signaling, inhibition of invasion and metastasis and increasing the

effectiveness of current chemotherapeutics. Low levels of curcumin enhance mitochondrial biogenesis in cells and tissues, mainly through the induction of the PGC- $1 \alpha$-related signaling pathway.

Study evaluates the possible anti-apoptotic, antioxidant and anti-inflammatory effects of curcumin on the neurotoxicity caused by Acrylamide (ACR) in rats. Curcumin increased TERT mRNA expression level, suggesting curcumin might exert anti-apoptotic activity in ACR-induced neurotoxicity partly through maintaining TERT-related anti-apoptotic function. Curcumin at the dose of $100 \mathrm{mg} / \mathrm{kg}$ significantly decreased the levels MDA and

IL- $1 \beta$ and TNF- $\alpha$; increased levels GSH and SOD.

\begin{tabular}{c}
\hline G2/M arrest via \\
possible inhibition of cell \\
cycle-related proteins including \\
Cyclin-dependent kinase 1 (CDK1), \\
cyclin B1, and "cell division cycle" \\
(CDC25C). Extracellular \\
signal-regulated kinase \\
Liu, et al. [72] $\quad$ ERK1/2) and Protein Kinase B (Akt) \\
pathways. Transforming growth \\
factor- $\beta$ (TGF- $\beta$ )/Smad pathway. \\
Notch signaling pathway.
\end{tabular}

V miR-21

in SU-DHL-8 cells,

Chen, et al. [73] regulating Von Hippel-Lindau

(VHL) expression in diffuse large B-cell lymphoma (DLBCL) cell line.
This study shows that curcumin could suppress the proliferation and epithelial-mesenchymal transition (EMT) in lens epithelial cells (LECs) and it might be a potential therapeutic protection against visual loss induced by posterior capsule opacification (PCO).
Curcumin exerts its anti-cancer effects, partly by targeting special microRNAs, in human cancers. MiR-21 is a key oncomir in carcinogenesis of multiple human cancers. Curcumin exerted its anti-proliferation, anti-migration, anti-invasion, and pro-apoptosis functions, at least partly, by repressing miR-21 and regulating VHL expression in DLBCL cell line. Study proved a possible molecular mechanism of curcumin-mediated anti-cancer effect. 
Table 1. Cont.

\begin{tabular}{|c|c|c|c|}
\hline Biological Effects & References & $\begin{array}{c}\text { Molecular Targets/Pathogenic } \\
\text { Pathways }\end{array}$ & Conclusions \\
\hline & Ma, et al. [74] & $\begin{array}{c}\text { Caspase } 3 \text { and BAX (protein } \\
\text { Bcl-2-associated X) } \\
\text { reducing the expression } \\
\text { of Bcl-2 in (human tongue } \\
\text { squamous cell carcinoma) CAL } \\
27 \text { cells } \mathbf{\nabla}\end{array}$ & $\begin{array}{l}\text { This study focused on the mechanism } \\
\text { underlying the therapeutic effect of } \\
\text { curcumin against tongue cancer (TC). The } \\
\text { effects of curcumin at different } \\
\text { concentrations on the proliferation, } \\
\text { migration, apoptosis, and cell cycle for TC } \\
\text { cells were verified in vitro. Study revealed } \\
\text { the anti-proliferative and pro-apoptotic } \\
\text { roles of curcumin in CAL } 27 \text { cells, probably } \\
\text { due to its role in modulating oxygen } \\
\text { production and metabolism. Curcumin } \\
\text { might be explored as a promising } \\
\text { therapeutic method to improve } \\
\text { TC treatment. }\end{array}$ \\
\hline & Muangnoi, et al. [75] & $\begin{array}{c}\text { Caspase-3 and }-9 \text { activities and } \\
\text { expression } \boldsymbol{\Delta} \\
\text { Bax and Bcl-2 protein expression } \\
\text { LC3-II protein level } \boldsymbol{\Delta}\end{array}$ & $\begin{array}{l}\text { The aims of the present study were to } \\
\text { determine the anti-proliferative effects and } \\
\text { mechanisms of curcumin diethyl } \\
\text { disuccinate (CurDD), a succinate ester } \\
\text { prodrug of Curcumin (Cur), in vitro, in } \\
\text { comparison with Cur. These results } \\
\text { indicated that the bioavailable fraction (BF) } \\
\text { of CurDD had anti-proliferation effect on } \\
\text { HepG2 cells by apoptosis induction in } \\
\text { HepG2 cells at significantly higher levels } \\
\text { than that of Cur. Incubation of HepG2 cells } \\
\text { with the BF of Cur increased caspase-3 } \\
\text { and -9 activities. } \\
\text { These results indicated that treatment of } \\
\text { HepG2 cells with the BF of CurDD } \\
\text { increased and, respectively, } \\
\text { decreased the expression } \\
\text { of Bax and Bcl-2 proteins, to a higher extent } \\
\text { than in the case of the BF of Cur. The BF of } \\
\text { CurDD increased the level of LC3-II } \\
\text { significantly higher than the BF of Cur. }\end{array}$ \\
\hline
\end{tabular}

\section{Curcumin and the Preventive Role in Hepatocellular Carcinoma}

In 2015, approximately 257 million people worldwide were chronic carriers of the hepatitis B virus, at risk for severe complications and liver cancer [76,77].

Chronic liver infection with HBV may eventually lead to liver cirrhosis and hepatocellular carcinoma [78], which are major complications and leading causes of death worldwide $[79,80]$.

From over 350 million people infected with HBV worldwide, approximately 600,000 people die from chronic end-stage HBV hepatitis and hepatocellular carcinoma; currently, HBV hepatitis is a major public health problem $[81,82]$.

The International Agency for Research on Cancer reported in 2018 more than 360,000 new cases of hepatocellular carcinoma secondary to HBV infection and about 160,000 new cases after hepatitis C virus infection, representing $76 \%$ of all etiologies of this form of cancer $[76,83]$.

Hepatocellular carcinoma (HCC), estimated as the sixth most common cancer in the world, is a complex malignancy, insidiously installed and diagnosed late, with a severe prognosis and whose incidence has doubled, becoming the third leading cause of death from cancer worldwide [76,84-86].

Since the early 1980s, a comprehensive HBV immunization program has been introduced as a global preventive measure; World Health Organization is currently supporting this program and has proposed that HBV and HCV infections be eradicated by 2030 [76].

Although modern, direct-acting antiviral drugs have brought a substantial benefit in the therapy of HCV infection with very good rates $(>90 \%)$ of sustained virologic response and high safety in the advanced stages of the disease, these agents have a disadvantage because they cannot be used extensively for the reason that they have high prices for some patients in the world's poor countries, and, on the other hand, there are studies that report the recurrence of the disease and the risk of HCC [79]. 
The main goal of chronic hepatitis B therapy is to reduce viral replication and stop disease progression and local and systemic complications. However, to date, HBV infection has not yet been eradicated because current drug therapies fail to remove covalently closed circular DNA from the patient's host cells [87].

In case of chronic HBV infection, the drug Lamivudine was first introduced in the therapy of this pathology as an inhibitor of hepatitis B virus reverse transcriptase HBV RT. Lamivudine works as an anti-polymerase/RT activity by inhibiting HBV DNA elongation and, after a few weeks of treatment, reduces by 34 logs of HBV plasma DNA, decreases disease activity, and reshapes the histological structure of the liver $[88,89]$.

Long-term use of Lamivudine frequently causes viral resistance with the possibility of virus replication. The incidence of Lamivudine resistance was reported in $14 \%$ to $32 \%$ after the first 12 months of treatment, over $38 \%$ after 24 months of treatment, and between $53 \%$ and $76 \%$ after 36 months of initiation of therapy [90].

In recent decades, more information has been obtained on the life cycle of $\mathrm{HBV}$, genetic variability, and pathogenesis. Sequencing of the HBV polymerase (Pol) gene allowed the identification of mutants that occur in the coding of viral polymerase, surface antigen, nucleus, and protein $X$. The effect of these mutations is also that of resistance to current drugs. The emergence of resistance to antiviral drugs used, poor efficacy in some cases, high costs, and side effects have led to research into herbal antiviral products in the treatment of chronic liver infection and complications such as cirrhosis and hepatocellular carcinoma [77,90-95].

Turmeric is the flowering plant Curcuma longa of the ginger family, Zingiberaceae. Curcumin (bis- $\alpha, \beta$-unsaturated $\beta$-dietone) is a polyphenol extracted from the plant Curcuma longa that has proven its chemopreventive capacity in carcinogenesis by targeting signaling pathways, regulating the expression of cell adhesion and inhibition of cell proliferation, migration, invasion, angiogenesis, and tumor metastases [96-100].

Curcumin is known as a powerful oxidant, which can stabilize the systems of anti-oxidant enzymes of the liver, reduce the level of superoxide anions $\left(\mathrm{O}^{2-}\right)$, hydroxyl radicals $\left(\mathrm{OH}^{-}\right)$, and increase the level of antioxidants by activating superoxide dismutase (SOD), glutathione peroxidase (GPx), and glutathione S-transferase (GST) [101,102].

Through its polyphenolic action, curcumin works competitively with an inhibitory role on the two isoforms of the enzyme inosine monophosphate dehydrogenase (IMPDH), which is a regulator of intracellular guanine nucleotides. It also plays a particularly important role in signal transduction, energy transfer, glycoprotein synthesis, DNA, RNA, and other multiple processes for cell vitality and proliferation $[103,104]$.

Experimental research of the aqueous extract of Curcuma longa rhizome used against HepG 2.2.15 cells containing HBV in their genome showed the suppression of HBsAg secretion from liver cells and mRNA production, without cytotoxic effects. At the same time, a suppression of HBV viral replication was found by transactivating and transcribing the p53 gene (p53 gene like the Rb gene, is a tumor suppressor gene) with increasing p53 protein production [105].

The chemopreventive effect of phytosomal curcumin in the occurrence of HCC in hepatitis B virus was also demonstrated by Teng et al. on a transgenic mouse model [19].

The study started from the fact that in the pathogenesis and progression of HCC was known the role of two viral oncoproteins HBV, hepatitis B X protein (HBx), and pre-S2 as surface mutants [106,107].

It will take a long period, of at least 10-30 years, from the onset of HBV infection to the diagnosis of HCC. Numerous mutations occur throughout the HBV genome. HBx protein mutants on the HBV surface are known to interfere with the processes of stimulation, activation of signaling pathways in liver cells, DNA repair, cell metabolism, proliferation, and apoptosis [108,109].

The pre-S2 protein, another surface mutant, accumulates in the hepatocyte endoplasmic reticulum (ER), mediates the activation of several oxidative stress-dependent pathways, and induces genomic instability and hepatocyte proliferation, involving NF- $\mathrm{kB}$ and p38 to regulate cyclooxygenase-2 (COX-2) 
and vascular endothelial growth factor A (VEGF-A). Teng et al. [19] claim that transgenic mice that have the two HBV oncoproteins can be selected as an experimental model in the production of drugs for preventive and therapeutic purposes in hepatocarcinogenesis.

Its properties as an anti-inflammatory agent, along with its strong antioxidant capacity, have increased interest in curcumin as a therapy for chronic liver disease. Several studies report that curcumin is a potent anti-inflammatory agent and can modulate nuclear factor kappa beta (NF-kB); inhibit phospholipases, cyclooxygenase-2 (COX-2), and 5-lipoxygenase (5-LOX); and decrease the concentrations of TNF alpha, IL-1, IL-6, and agonist of peroxisome proliferator-activated receptor gamma (PPAR $\gamma$ ), which has an important role in inhibiting pro-inflammatory pathways [110-113].

Phytosomal curcumin has been shown experimentally to have effects on peroxisome proliferator-activated receptor gamma (PPAR $\gamma$ ) anti-inflammatory activation, pro-inflammatory NF- $\mathrm{kB}$ inhibition, suppression of mammalian target of rapamycin (mTOR) deactivation oncogene, improvement of hepatic histopathology (steatosis and necroinflammation), and reduction in volume HCC [106].

The chemoprotective role in HCC would be achieved through the following cellular processes: $\operatorname{PPAR} \gamma$ will be produced at the beginning, then heterodimers will form between PPAR $\gamma$ and the retinoid $\mathrm{X}$ receptor, which will attract coactivators and bind to the peroxisome proliferator response structures and, thus, regulate the genes of lipid metabolism, anti-inflammatory, and anti-cell proliferative function [114].

Activated PPARy inhibits NF- $\mathrm{kB}$ activation, which will induce suppression of NF-B-mediated pro-inflammatory cytokine transcription $[115,116]$ and will inhibit mTOR-mediated highway oncogenic signal activation (mammalian target of rapamycin or sometimes also called mechanistic target of rapamycin) $[117,118]$.

These aspects recommend phytosomal curcumin to be considered as a promising alternative in the long-term treatment, with a chemopreventive role in the occurrence of HCC in patients with chronic HBV infection.

An interesting observation was revealed by epidemiological studies conducted in India, which showed the reduced incidence of digestive cancer through the consumption of Curcuma longa, which has proven antioxidant and chemopreventive properties [119].

A recent study focused on the role of hepatic stellate cells (HSC) in the emergence and progress of HCC and the possible protective effect of curcumin. HSCs have a special role in the secretion of soluble factors, such as IL-6, vascular endothelial growth factor (VEGF), and stromal cell-derived factor 1 (SDF-1), and in increasing the level of reactive oxygen species (ROS) to modulate expression of the hypoxia-inducible factor 1-alpha (HIF-1 $\alpha$ ) in promoting the process of angiogenesis, epithelial-mesenchymal transition (EMT), HCC invasion, and progression. The study data show that curcumin induces protection in the appearance of HCC by purifying ROS and glutathione (GSH), thus blocking HIF-1 and suppressing the expression of connective tissue growth factor (CTGF). The results are promising for the therapeutic effect of curcumin in HCC [120].

In an experimental study to induce the occurrence of HCC by diethylnitrosamine (DEN) in mice, the association among curcumin, leflunomide, and perindopril related to various angiogenic pathways was used as chemoprevention therapy; thus, synergistic inhibition of angiogenesis and prevention of HCC development was achieved [121].

Another major problem in the success of HBV eradication therapy in infected individuals is the persistence of cccDNA residue (covalently closed circular DNA). It is already known from the mode of action of HBV that after the virus invades the cell and rcDNA (partially double-stranded relaxed circular DNA) is left free in the cell nucleus and then converted into covalently closed circular DNA (cccDNA), which is actually a mini chromosome that prints a histonic link. So, HBV infection becomes persistent and recurrent, because this cccDNA structure will serve as a template for mRNA synthesis and viral replication $[122,123]$. 
More and more therapeutic protocols with various drugs (nucleoside analogues, disubstituted sulfonamide compounds, cytidine deaminases, zinc-finger nucleases) manage to inhibit HBV replication, but do not rid the cell of ccDNA residue and, worse, recent therapies can target human homologous sequences [124-129].

Curcumin may inhibit HBV activity by decreasing the role of the peroxisome proliferator-activated receptor- $\gamma$ coactivator (PGC)-1 $\alpha$ [15] or otherwise, via activating transcription and growth of the p53 [105].

Another hypothesis is that curcumin inhibitory activity in HBV infection is achieved by inhibiting the function of histone acetyltransferase p300 (multifunctional transcriptional coactivator that interacts with numerous transcription factors and protein/histone acetyltransferase activity) that will lead to histone deacetylation related to cccDNA $[130,131]$.

This hypothesis was the basis of an experimental study on a HepG2.2.15 cell line stably transfected with HBV and curcumin treated, after which the ELISA technique assessed the expression levels of HBV surface antigen HBsAg, and HBeAg antigen. Depending on the dose and time, curcumin decreased the expression of HBsAg and $\mathrm{HBeAg}$ and played a significant role in remarkably reducing the replication of the intracellular HBV DNA intermediates and HBV cccDNA. In the end, the study proved that curcumin would inhibit HBV gene replication by reducing cccDNA-bound histone acetylation processes and would have a cccDNA-targeted antiviral agent perspective in chronic HBV infection [18].

Curcumin, the polyphenolic compound [132] with antioxidant, anti-inflammatory, antiviral, and chemoprotective properties alone or in combination with other agents or even with the blue laser [133], could be an effective drug for therapy and cancer prevention [134].

\section{Photodynamic Therapy with Blue Laser and Curcumin in Hepatic Viral Infections}

Although the therapeutic properties of light have been known for thousands of years, only in the last two centuries the photodynamic therapy (PDT) has been developed.

PDT is a modern treatment that uses light (phototherapy) together with a light-sensitive chemical that, in the presence of molecular oxygen, causes cell death in the target tissue by phototoxicity.

Anti-infectious, light-mediated effect was rediscovered by chance in 1900: Paramecium caudatum incubated with acridine died when exposed to certain wavelengths, but only in the presence of oxygen [135].

One year later, Niels Finsen ingeniously used light therapy for smallpox and skin tuberculosis, and in 1903 won the Nobel Prize for his phototherapy work [136] "in recognition of his contribution to the treatment of diseases, especially lupus vulgaris, with concentrated light radiation, whereby he has opened a new avenue for medical science" [137].

The term "photodynamic" was for the first time used in 1907 by Herman von Tappeiner, who defined the photodynamic action [138].

Since then, PDT became a well-studied therapy for infections, nonmalignant diseases [139], and in some countries has become a standardized protocol alongside radiotherapy and chemotherapy in anticancer treatments.

The purpose of PDT is to induce various cellular responses, from the inactivation of bacteria and viruses to the necrosis or apoptosis of pathological cells, using the three absolutely necessary elements: Laser light, molecular oxygen, and a nontoxic, light-sensitive substance, named photosensitizer (PS).

The first photosensitizer, called "hematoporphyrin derivative" $(\mathrm{HpD})$ or, later (when purified), "Photofrin", was invented by Dr. Thomas Dougherty and colleagues in 1970 at Roswell Park's Department of Experimental Biology, USA, from a mixture of water-soluble porphyrins. With this product he began to successfully treat cancer with PDT in preclinical models, and in 1975 he treated the first cases of skin cancer. In 1978, Dr. Dougherty carried out the first human clinical trial with control group [136].

It turned out that the method acted not only on the tumor, but also destroyed the blood supply of the remaining cancer cells around the tumor, preventing their proliferation and expansion. After treatment, 
the procedure induces inflammatory and immune responses and research has shown that the extensive action on the immune system makes it able to target and eliminate other cancer cells from the body [140].

Photosensitizers (PS) are pure chemicals with a well-specified composition, which, when introduced into the body, will preferentially accumulate in the target tissue and, after irradiation with a certain wavelength in the visible range, absorb it strongly and pass through a singlet state, followed by a long-lasting excited triplet state, during which cytotoxic reactive oxygen species (ROS) are generated through various intrinsic mechanisms, which will interact with pathogenic agents and malignant cells and tissues, which they will destroy.

Although it is still widely used, Photofrin, as a photosensitizer from first generation, has disadvantages including a relatively low absorption maximum at $630 \mathrm{~nm}$ (so, difficult to use for large malignancies, where light penetration will be more difficult throughout the whole volume) and, for the patients, the residual photosensitivity of the skin over several weeks or even months can bother and irritate them greatly $[136,141]$.

PDT has been extensively investigated and applied in the last decades, proving to be an effective method of treatment. As a two-step procedure, PDT begins with the administration of the photosensitizer, followed by exposure to light, in order to obliterate the pathogens or the malignant structures [142].

Subsequently, acute inflammatory processes trigger warning signals to the adaptive arm of innate immune system for generating the specific cytotoxic T lymphocytes that have the capability to directly identify and eliminate the self-altered cells and release even more mediators.

This effect of the adaptive immune response has highlighted in recent years the great value of PDT for long-term control and immune memory to stop recurrences [143].

Due to all these aspects and proving to be a minimally invasive treatment modality, the intense interest for PDT has increased exponentially. The global efficacy of PDT overlies the characteristics of activation laser light and in situ dosimetry (selection of PS, wavelength of light, and layout of the target tissue and its small-scale environment) [144].

When put into action appropriately, PDT has no long-term undesirable secondary effects, can be applied with maximum accuracy, is not as invasive as other treatment modalities, can be repeated many times at the same site if needed, is most often less expensive, and can be done as outpatient therapy [145]. However, with all its proven success, PDT is still underrated and not so widely used [142].

Also, interstitial photodynamic therapy (I-PDT) is showing signs of future success for advanced well-localized cancers but can be encountered only in few clinics [146].

Cancer stem cell model opened new plans of action designed to achieve the major aims: Efficient treatment and cancer's prophylaxis, targeting signaling pathways such as Wnt, Notch, and Hedgehog (Hh) with natural compounds, for example, curcumin, in order to minimize the risk of relapses [147].

Due to the fact that curcumin is a potent inhibitor of NF- $\mathrm{KB}$ signaling and of the expression of viral oncogenes E6 and E7, in decreasing the integrase and viral protease of HIV-1, in the intracellular accumulation of p53, and, consequently, in decreasing the RNA level of intracellular HBV, several studies have been performed in an attempt to use it as a photosensitizer in photodynamic therapy [148].

PDT as a state-of-the-art medical technology, using blue light $(400-470 \mathrm{~nm})$, can effectively fight bacterial, fungal, and viral infections.

Photoreceptors, which are specific cellular structures, can absorb only specific wavelengths of light.

Light interaction with these photoreceptors will trigger a cascading cellular signal, which will affect the chemical behavior, the metabolism, the movement, and the expression of genes inside the cell. All associated enzymes and/or proteins will be affected [133].

An example for the absorption of different wavelengths inside cells is the process in the mitochondrial respiratory chain, where complex 1 (NADH dehydrogenase) absorbs blue and ultraviolet light [133]. 
Blue light releases nitric oxide (NO), known to be a growth, immune, and neuro-modulator, as well as a stimulator of stem cell proliferation, playing critical roles in pain reduction, vasodilation, and angiogenesis through c-GMP (cyclic guanosine monophosphate) pathway.

The blue laser has a strong anti-inflammatory effect by reducing proinflammatory cytokines (for example, IL2, IL6, TNF-alpha) and acts on cellular signaling pathways (e.g., NF-kB) and other factors that contribute to a variety of diseases (CRP, leptin, chemokines, etc.).

Blue light is effective in treating infections by producing ROS (especially in combination with photosensitive substances such as riboflavin or curcumin) $[17,133]$.

Great efforts are currently being made to explore the clinical value of blue light in the fight against viral infections, an example being the current COVID-19 pandemic [149].

The important bactericidal effect of blue light spectrum when acting on most microbes has been demonstrated; pulsed wave blue light is more efficient than continuous wave [150].

In addition to blue light laser devices, updated technology has designed and manufactured LED devices that are much cheaper and easier to use by patients to fight viral infections, even at home $[149,150]$.

The review of scientific papers published so far shows that the antibacterial effect is caused by the action of blue light that activates endogenous bacterial chromophores and photosensitive receptors that release reactive oxygen species (ROS) capable of triggering cellular apoptosis.

Another possible mechanism would be the action of blue light on the integrity of the cell membrane, with the decrease of the transmembrane potential and, consequently, the rapid disturbance of cellular functions [151].

The latest possible mechanisms by which blue light would annihilate bacteria, currently proposed but requiring further scientific studies to be confirmed, refer to the modification of A-DNA and the upregulation of the prophage genes $[149,152,153]$.

PDT with blue light in the $420-430 \mathrm{~nm}$ wavelength band (the maximum absorption of curcumin) applied to blood plasma inactivates herpes simplex virus and human immunodeficiency virus, and prolonged exposure to blue light inactivates leukemia virus (in murine) [154-157].

Particular problems raised by viral infections are those related to current ineffective drugs for many viral diseases, the emergence of resistance, sometimes formidable side effects, and high costs, which have led specialists to discover new compounds or effective antiviral treatment [103].

Due to the 15 different polyphenols it contains, curcumin has an exceptional antiviral activity, competing with inosine monophosphate dehydrogenase (IMPDH), an enzyme that limits starting just from the beginning the synthesis of guanine nucleotides and which activates signaling pathways in the evolution of viral infections to neoplasms [158].

The antitumor effects of curcumin are due not only to its action on various signaling pathways, but also on potentiating the efficacy of the immune system for removing the tumor cells just from the beginning of the proliferative processes, suppressing the neoplasm development [159].

Bose et al. highlighted the immunomodulatory role of curcumin by affecting the ratio of CD4 (+) $\mathrm{T}$ cells/CD8 (+) T cells, with the decrease of Treg cells and the suppression of $\mathrm{T}$ cell apoptosis restoring the immune vigilance against tumor cells and, consequently, the retrogression of the tumor [160].

At the initiation of the tumor process, naïve $T$ cells have a special role because they are becoming operative, set into motion the microenvironment of the tumor formation, and fight to remove immunogenic neoplastic cells [161].

Cytotoxic T lymphocytes (CTL) arise from the differentiation of CD8+ T cells, which play the leading role as antitumor cells; meanwhile, CD4+ T helper1 (Th-1) will support the T cell switch on, increase the CTL cytotoxicity, and can foster the development of the antineoplastic task of the macrophages and NK cells, generating different pro-inflammatory cytokines [162,163].

Curcumin could transform regulatory T cells into helper T cells (Th-1), with antitumor results [159]. 
The anticancer activity of curcumin by targeting and modifying the regulatory $\mathrm{T}$ cells into $\mathrm{T}$ helper ones, could be enhanced by the blue laser photobiomodulation so that HBV-infected hepatocytes are more easily eliminated.

Because curcumin proved to be a very good photosensitizer used also in the food industry, Randazzo W. et al. [164] measured the antiviral activity of blue light-photoactivated curcumin on surrogate norovirus, feline calicivirus (FCV), and murine norovirus (MNV).

PDT with LEDs' blue light-activating curcumin with $3 \mathrm{~J} / \mathrm{cm}^{2}$ against MNV-1 distorted the viral capsid and reduced FCV titers, so that photoactivated curcumin could be used in food security to reduce viral contamination [164].

Even without being illuminated, curcumin has a very good effect on the microvessels in the circulatory system, impact that is maximized by lighting, resulting in a faster decrease of an important number of vessels and their diameter under the action of light and curcumin, with important applications in the vascular pathology and the control of blood supply in case of tumors [165].

\section{Conclusions}

Blue laser light and UltraBioavailable Curcumin could be a new, valuable alternative for medical applications in chronic B viral hepatitis and hepatocellular carcinoma, saving millions of lives.

Author Contributions: Conceptualization, L.M.A.; writing and original draft preparation, L.M.A.; review and editing, G.L. and L.M.A. All authors have read and agreed to the published version of the manuscript.

Funding: This project is funded by the Ministry of Research and Innovation within Program 1-Development of the national RD system, Subprogram 1.2-Institutional Performance-RDI excellence funding projects, Contract no.34PFE/19.10.2018, Romania.

Conflicts of Interest: The authors declare no conflict of interest.

\section{Abbreviations}

$\begin{array}{ll}\text { AN } & \text { Analog nucleotides } \\ \text { ccCDNA } & \text { Covalently closed circular DNA } \\ \text { GHSS } & \text { Global Health Sector Strategy } \\ \text { HCC } & \text { Hepatocellular carcinoma } \\ \text { HCV } & \text { Hepatitis C virus } \\ \text { HBV } & \text { Hepatitis B virus } \\ \text { IFN } & \text { Interferon } \\ \text { IVBLBI } & \text { Intravenous blue laser blood irradiation } \\ \text { MCP-1 } & \text { Monocyte chemoattractant/chemotactic protein-1 } \\ \text { PBM } & \text { Photobiomodulation } \\ \text { PDT } & \text { Photodynamic therapy } \\ \text { ROS } & \text { Reactive oxygen species } \\ \text { WHO } & \text { World Health Organization }\end{array}$

\section{References}

1. The, L. Stem cells, regenerative medicine, and Prometheus. Editorial. Lancet 2018, 391, 814. [CrossRef]

2. Hamblin, M.R. Mechanisms and applications of the anti-inflammatory effects of photobiomodulation. AIMS Biophys. 2017, 4, 337-361. [CrossRef] [PubMed]

3. Weber, M.H. Basics, Science and Clinical Applications of Laserneedle Acupuncture. Available online: https://www.isla-laser.org/wp-content/uploads/Prsentation-LA-1-Basics-and-External-Laser-Therapy.pdf (accessed on 29 July 2019).

4. WHO. Global Hepatitis Report. 2017. Available online: http://www.who.int/hepatitis/publications/globalhepatitis-report2017/en/ (accessed on 1 June 2019).

5. Bartosch, B. Hepatitis B and C Viruses and Hepatocellular Carcinoma. Viruses. 2010, 2, 1504-1509. [CrossRef] [PubMed] 
6. Parkin, D.M.; Bray, F.; Ferlay, J.; Pisani, P. Estimating the world cancer burden: Globocan 2000. Int. J. Cancer. 2001, 94, 153-156. [CrossRef] [PubMed]

7. Kim, H.S.; El-Serag, H.B. The Epidemiology of Hepatocellular Carcinoma in the USA. Curr. Gastroenterol. Rep. 2019, 21, 17. [CrossRef]

8. Castelli, G.; Pelosi, E.; Testa, U. Liver cancer: Molecular characterization, clonal evolution and cancer stem cells. Cancers 2017, 9, 127. [CrossRef]

9. Dorobantu, M. "State of Innovation": Interferon-Free Therapies Have the Potential to Eliminate Hepatitis C. Available online: https://raportuldegarda.ro/articol/state-of-innovation-terapiile-interferon-free-hepatita-c/ (accessed on 1 June 2019).

10. Obretin, D. What Do We Need to Know about Hepatitis B Virus Infection? Available online: https: //doc.ro/hepatita-c/ce-trebuie-sa-stim-despre-infectia-cu-virusul-hepatitei-b (accessed on 1 June 2019).

11. Loomba, R.; Liang, T.J. Hepatitis B reactivation associated with immune suppressive and biological modifier therapies: Current concepts, management strategies, and future directions. Gastroenterology 2017, 152, 1297-1309. [CrossRef]

12. Huang, Q.; Zhou, B.; Cai, D.; Zong, Y.; Wu, Y.; Liu, S.; Guo, H.; Sun, J.; Hou, J.; Colonno, R. THU-216-Rapid turnover of $\mathrm{HBV}$ cccDNA in nucleoside-treated chronic hepatitis $\mathrm{B}$ patients during drug resistance emergence and breakthrough. J. Hepatol. 2019, 70, e258-e259. [CrossRef]

13. Suk-Fong Lok, A. Hepatitis B treatment: What we know now and what remains to be researched. Hepatol. Commun. 2018, 3, 8-19. [CrossRef]

14. Bruzell, E.M.; Morisbak, E.; Tonnesen, H.H. Studies on curcumin and curcuminoids. XXIX. Photoinduced cytotoxicity of curcumin in selected aqueous preparations. Photochem. Photobiol. Sci. 2005, 4, 523-530. [CrossRef]

15. Rechtman, M.M.; Har-Noy, O.; Bar-Yishay, I.; Fishman, S.; Adamovich, Y.; Shaul, Y.; Halpern, Z.; Shlomai, A. Curcumin inhibits hepatitis B virus via down-regulation of the metabolic coactivator PGC-1alpha. Febs. Lett. 2010, 584, 2485-2490. [CrossRef] [PubMed]

16. Mirzaei, H.; Shakeri, A.; Rashidi, B.; Jalili, A.; Banikazemi, Z.; Sahebkar, A. Phytosomal curcumin: A Review of pharmacokinetic, experimental and clinical studies. Biomed. Pharmacother. 2017, 85, 102-112. [CrossRef] [PubMed]

17. Weber, M.; Weber, R.; Junggebauer, M. Photodynamic low-level-laser therapy. Chapter 6. In Medical Low-Level Laser Therapy-Foundations and Clinical Applications-Research Book, 2nd ed.; ISLA-International Society for Medical Laser Applications: Beverungen, Germany, 2015; pp. 431-465. ISBN 978-3-00-050017-6.

18. Wei, Z.Q.; Zhang, Y.H.; Ke, C.Z.; Chen, H.X.; Ren, P.; He, Y.L.; Hu, P.; Ma, D.Q.; Luo, J.; Meng, Z.J. Curcumin inhibits hepatitis B virus infection by down-regulating cccDNA-bound histone acetylation. World J. Gastroenterol. 2017, 23, 6252-6260. [CrossRef] [PubMed]

19. Teng, C.F.; Yu, C.H.; Chang, H.Y.; Hsieh, W.C.; Wu, T.H.; Lin, J.H.; Wu, H.C.; Jeng, L.B.; Su, I.J. Chemopreventive effect of phytosomal curcumin on hepatitis B virus-related hepatocellular carcinoma in a transgenic mouse model. Sci. Rep. 2019, 9, 10338. [CrossRef]

20. Kunwar, A.; Barik, A.; Priyadarsini, K.I.; Pandey, R. Absorption and fluorescence studies of curcumin bound to liposome and living cells. Barc. Newsl. 2007, 285, 213.

21. Lubart, R.; Lipovski, A.; Nitzan, Y.; Friedmann, H. A possible mechanism for the bactericidal effect of visible light. Laser Ther. 2011, 20, 17-22. [CrossRef]

22. Habiboallah, G.; Mahdi, Z.; Mahbobeh, N.N.; Mina, Z.J.; Sina, F.; Majid, Z. Bactericidal effect of visible light in the presence of erythrosine on Porphyromonas gingivalis and Fusobacterium nucleatum compared with diode laser, an in vitro study. Laser Ther. 2014, 23, 263-271.

23. Mahdi, Z.; Habiboallh, G.; Mahbobeh, N.N.; Mina, Z.J.; Majid, Z.; Nooshin, A. Lethal effect of blue light-activated hydrogen peroxide, curcumin and erythrosine as potential oral photosensitizers on the viability of porphyromonas gingivalis and fusobacterium nucleatum. Laser Ther. 2015, 24, 103-111. [CrossRef]

24. Intravenous Laser Therapy. Available Laser Modules. Blue 405 and $447 \mathrm{~nm}$. Available online: https: //www.webermedical.com/index.php?id=27\&lang=en (accessed on 4 August 2019).

25. Tsen, K.T.; Tsen, S.W.D.; Chang, C.L.; Hung, C.F.; Wu, T.C.; Kiang, J.G. Inactivation of viruses by coherent excitations with a low power visible femtosecond laser. Virol. J. 2007, 4, 50. [CrossRef] 
26. Tsen, K.T.; Tsen, S.W.D.; Chang, C.L.; Hung, C.F.; Wu, T.C.; Kiang, J.G. Inactivation of viruses with a very low power visible femtosecond laser. J. Phys. Condens. Matter. 2007, 19, 2102-2109. [CrossRef]

27. Tsen, K.T.; Tsen, S.W.D.; Fu, Q.; Lindsay, S.M.; Kibler, K.; Jacobs, B.; Wu, T.C.; Karanam, B.; Jagu, S.; Roden, R.B.; et al. Photonic approach to the selective inactivation of viruses with a near-infrared subpicosecond fiber laser. J. Biomed. Opt. 2009, 14, 064042. [CrossRef] [PubMed]

28. Tsen, K.T.; Cope, S.; Vaiana, S.; Tsen, S.W.D.; Fu, Q.; Lindsay, S.M.; Li, Z.; Kiang, J.G. Studies of inactivation of encephalomyocarditis virus, M13 bacteriophage, and Salmonella typhimurium by using a visible femtosecond laser: Insight into the possible inactivation mechanisms. J. Biomed. Opt. 2011, 16, 078003. [CrossRef] [PubMed]

29. Tsen, S.W.D.; Chapa, T.; Beatty, W.; Tsen, K.T.; Yu, D.; Achilefu, S. Inactivation of enveloped virus by laser-driven protein aggregation. J. Biomed. Opt. 2012, 17, 128002. [CrossRef] [PubMed]

30. Tsen, S.W.D.; Kingsley, D.H.; Poweleit, C.; Achilefu, S.; Soroka, D.S.; Wu, T.C.; Tsen, K.T. Studies of inactivation mechanism of non-enveloped icosahedral viruses by a visible ultrashort pulsed laser. Virol. J. 2014, 11, 20. [CrossRef] [PubMed]

31. Kingsley, D.; Kuis, R.; Perez, R.; Basaldua, I.; Burkins, P.; Marcano, A.; Johnson, A. Oxygen-dependent laser inactivation of murine norovirus using visible light lasers. Virol. J. 2018, 15, 117. [CrossRef]

32. Chiran, D.A.; Litscher, G.; Weber, M.H.; Ailioaie, L.M.; Ailioaie, C.; Litscher, D. Intravenous laser blood irradiation increases efficacy of etanercept in selected subtypes of juvenile idiopathic arthritis: An innovative clinical research approach. Evid. Based Complement. Altern. Med. 2013. [CrossRef]

33. Moskvin, S.V.; Kisselev, S.B. Laser Therapy for Joint and Muscle Pain; Triada: Sewickley, PA, USA, 2017; Volume 216, pp. 175-176. ISBN 978-5-94789-787-6.

34. Moskvin, S.V.; Khadartsev, A.A. Basic Techniques of Low Level Laser Therapy; Triada: Sewickley, PA, USA, 2017; Volume 144, pp. 11-12. ISBN 978-5-94789-772-2.

35. Zhu, H.; Kochevar, I.E.; Behlau, I.; Zhao, J.; Wang, F.; Wang, Y.; Sun, X.; Hamblin, M.R.; Dai, T. Antimicrobial blue light therapy for infectious keratitis: Ex vivo and in vivo studies. Investig. Ophthalmol. Vis. Sci. 2017, 58.1, 586-593. [CrossRef]

36. Dai, T.; Gupta, A.; Murray, C.K.; Vrahas, M.S.; Tegos, G.P.; Hamblin, M.R. Blue light for infectious diseases: Propionibacterium acnes, helicobacter pylori, and beyond? Drug Resist. Updat. 2012, 15, 223-236. [CrossRef]

37. El-Bacha, T.; Da Poian, A.T. Virus-induced changes in mitochondrial bioenergetics as potential targets for therapy. Int. J. Biochem. Cell Biol. 2013, 45, 41-46. [CrossRef] [PubMed]

38. Araújo, N.C.; Fontana, C.R.; Gerbi, M.E.M.; Bagnato, V.S. Overall-mouth disinfection by photodynamic therapy using curcumin. Photomed. Laser Surg. 2012, 30, 96-101. [CrossRef] [PubMed]

39. Karimian, M.S.; Pirro, M.; Majeed, M.; Sahebkar, A. Curcumin as a natural regulator of monocyte chemoattractant protein-1. Cytokine Growth Factor Rev. 2017, 33, 55-63. [CrossRef] [PubMed]

40. Jagetia, G.C.; Aggarwal, B.B. "Spicing up" of the immune system by curcumin. J. Clin. Immunol. 2007, 27, 19-35. [CrossRef] [PubMed]

41. Yang, C.; Zhu, K.; Yuan, X.; Zhang, X.; Qian, Y.; Cheng, T. Curcumin has immunomodulatory effects on RANKL-stimulated osteoclastogenesis in vitro and titanium nanoparticle-induced bone loss in vivo. J. Cell Mol. Med. 2020, 24, 1553-1567. [CrossRef] [PubMed]

42. Wu, T.; Marakkath, B.; Ye, Y.; Khobahy, E.; Yan, M.; Hutcheson, J.; Zhu, J.; Zhou, X.; Mohan, C. Curcumin attenuates both acute and chronic immune nephritis. Int. J. Mol. Sci. 2020, 21, 1745. [CrossRef] [PubMed]

43. Tuyaerts, S.; Rombauts, K.; Everaert, T.; Van Nuffel, A.M.T.; Amant, F. A phase 2 study to assess the immunomodulatory capacity of a lecithin-based delivery system of curcumin in endometrial cancer. Front. Nutr. 2019, 5, 138. [CrossRef] [PubMed]

44. Mollazadeh, H.; Cicero, A.F.G.; Blesso, C.N.; Pirro, M.; Majeed, M.; Sahebkar, A. Immune modulation by curcumin: The role of interleukin-10. Crit. Rev. Food Sci. Nutr. 2019, 59, 89-101. [CrossRef]

45. Boroumand, N.; Samarghandian, S.; Hashemy, S.I. Immunomodulatory, anti-inflammatory, and antioxidant effects of curcumin. J. Herbmed Pharm. 2018, 7, 211-219. [CrossRef]

46. Bai, X.; Oberley-Deegan, R.E.; Bai, A.; Ovrutsky, A.R.; Kinney, W.H.; Weaver, M.; Zhang, G.; Honda, J.R.; Chan, E.D. Curcumin enhances human macrophage control of mycobacterium tuberculosis infection. Respirology 2016, 21, 951-957. [CrossRef] 
47. Antiga, E.; Bonciolini, V.; Volpi, W.; Del Bianco, E.; Caproni, M. Oral curcumin (Meriva) is effective as an adjuvant treatment and is able to reduce IL-22 serum levels in patients with psoriasis vulgaris. BioMed. Res. Int. 2015, 283634. [CrossRef] [PubMed]

48. Castro, C.N.; Barcala Tabarrozzi, A.E.; Winnewisser, J.; Gimeno, M.L.; Noguerol, M.A.; Liberman, A.C.; Paz, D.A.; Dewey, R.A.; Perone, M.J. Curcumin ameliorates autoimmune diabetes. Evidence in accelerated murine models of type 1 diabetes: Curcumin ameliorates autoimmunity in NOD. Clin. Exp. Immunol. 2014, 177, 149-160. [CrossRef] [PubMed]

49. Lee, S.; Cho, S.; Li, Y.; Bae, C.S.; Park, K.M.; Par, D.H. Anti-inflammatory effect of curcuma longa and allium hookeri co-treatment via NF-kB and COX-2 pathways. Sci. Rep. 2020, 10, 5718. [CrossRef] [PubMed]

50. Li, C.L.; Zhou, W.; Ji, G.; Zhang, L. Natural products that target macrophages in treating non-alcoholic steatohepatitis. World J. Gastroenterol. 2020, 26, 2155-2165. [CrossRef]

51. Almatroodi, S.A.; Alrumaihi, F.; Alsahli, M.A.; Alhommrani, M.F.; Khan, A.; Rahmani, A.H. Curcumin, an active constituent of turmeric spice: Implication in the prevention of lung injury induced by benzo(a) pyrene $(\mathrm{BaP})$ in rats. Molecules 2020, 25, 724. [CrossRef]

52. Vitali, D.; Bagri, P.; Wessels, J.M.; Arora, M.; Ganugula, R.; Parikh, A.; Mandur, T.; Felker, A.; Garg, S.; Kumar, M.N.V.R.; et al. Curcumin can decrease tissue inflammation and the severity of HSV-2 infection in the female reproductive mucosa. Int. J. Mol. Sci. 2020, 21, 337. [CrossRef]

53. Ullah, M.A.; Johora, F.T.; Sarkar, B.; Araf, Y.; Rahman, M.H. Curcumin analogs as the inhibitors of TLR4 pathway in inflammation and their drug like potentialities: A computer-based study. J. Recept. Signal. Transduct. Res. 2020, 40, 324-338. [CrossRef]

54. Shimizu, K.; Funamoto, M.; Sunagawa, Y.; Shimizu, S.; Katanasaka, Y.; Miyazaki, Y.; Wada, H.; Hasegawa, K.; Morimoto, T. Anti-inflammatory action of curcumin and its use in the treatment of lifestyle-related diseases. Eur. Cardiol. 2019, 14, 117-122. [CrossRef]

55. Szebeni, G.J.; Nagy, L.I.; Berkó, A.; Hoffmann, A.; Fehér, L.Z.; Bagyánszki, M.; Kari, B.; Balog, J.A.; Hackler, L.; Kanizsai, I.; et al. The anti-inflammatory role of mannich curcuminoids; special focus on colitis. Molecules 2019, 24, 1546. [CrossRef]

56. Wal, P.; Saraswat, N.; Pal, R.S.; Wal, A.; Chaubey, M. A detailed insight of the anti-inflammatory effects of curcumin with the assessment of parameters, sources of ros and associated mechanisms. Open Med. J. 2019, 6, 64-76. [CrossRef]

57. Chen, L.; Liu, T.; Wang, Q.; Liu, J. Anti-inflammatory effect of combined tetramethylpyrazine, resveratrol and curcumin in vivo. BMC Complement. Altern. Med. 2017, 17, 233. [CrossRef] [PubMed]

58. Panahi, Y.; Hosseini, M.S.; Khalili, N.; Naimi, E.; Simental-Mendía, L.E.; Majeed, M.; Sahebkar, A. Effects of curcumin on serum cytokine concentrations in subjects with metabolic syndrome: A post-hoc analysis of a randomized controlled trial. Biomed Pharm. 2016, 82, 578-582. [CrossRef] [PubMed]

59. Paciello, F.; Rita Fetoni, A.; Mezzogori, D.; Rolesi, R.; Di Pino, A.; Paludetti, G.; Grassi, C.; Troiani, D. The dual role of curcumin and ferulic acid in counteracting chemoresistance and cisplatin-induced ototoxicity. Sci. Rep. 2020, 10, 1063. [CrossRef] [PubMed]

60. AlBasher, G.; Abdel-Daim, M.M.; Almeer, R.; Ibrahim, K.A.; Hamza, R.Z.; Bungau, S.; Aleya, L. Synergistic antioxidant effects of resveratrol and curcumin against fipronil-triggered oxidative damage in male albino rats. Env. Sci. Pollut. Res. 2020, 27, 6505-6514. [CrossRef]

61. Konak, S.; Şener, E.H. Antioxidant effects of curcumin on the blood tissue in rats. MAKU J. Health Sci. Inst. 2019, 7, 8-14. [CrossRef]

62. Nawab, A.; Li, G.; Liu, W.; Lan, R.; Wu, J.; Zhao, Y.; Kang, K.; Kieser, B.; Sun, C.; Tang, S.; et al. Effect of dietary curcumin on the antioxidant status of laying hens under high- temperature condition. J. Therm. Biol. 2019, 86, 102449. [CrossRef]

63. Nawab, A.; Li, G.; An, L.; Wu, J.; Chao, L.; Xiao, M.; Zhao, Y.; Birmani, M.W.; Ghani, M.W. Effect of curcumin supplementation on TLR4 mediated non-specific immune responses in liver of laying hens under high-temperature conditions. J. Biol. 2019, 84, 384-397. [CrossRef]

64. Meshkibaf, M.H.; Maleknia, M.; Noroozi, S. Effect of curcumin on gene expression and protein level of methionine sulfoxide reductase A (MSRA), SOD, CAT and GPx in Freund's adjuvant inflammation-induced male rats. J. Inflamm. Res. 2019, 12, 241-249. [CrossRef]

65. Borra, S.K.; Mahendra, J.; Gurumurthy, P.; Jayamathi; Iqbal, S.S.; Mahendra, L. Effect of curcumin against oxidation of biomolecules by hydroxyl radicals. J. Clin. Diagn. Res. 2014, 8, CC1-CC5. [CrossRef] 
66. Jat, D.; Parihar, P.; Kothari, S.C.; Parihar, M.S. Curcumin reduces oxidative damage by increasing reduced glutathione and preventing membrane permeability transition in isolated brain mitochondria. Cell Mol. Biol. 2013, 59, OL1899-OL1905.

67. Norooznezhad, F.; Rodriguez-Merchan, E.C.; Asadi, S.; Norooznezhad, A.H. Curcumin: Hopeful treatment of hemophilic arthropathy via inhibition of inflammation and angiogenesis. Expert Rev. Hematol. 2020, 13, 5-11. [CrossRef] [PubMed]

68. Mohapatra, T.K.; Nayak, R.R.; Subudhi, B.B. Exploration of anti-inflammatory and hepatoprotective effect of curcumin on co-administration with acetylsalicylic acid. J. Pharm. Pharmacogn. Res. 2019, 7, 310-322.

69. Hassan, F.U.; Rehman, M.S.; Khan, M.S.; Ali, M.A.; Javed, A.; Nawaz, A.; Yang, C. Curcumin as an alternative epigenetic modulator: Mechanism of action and potential effects. Front. Genet. 2019, 10, 514. [CrossRef] [PubMed]

70. Rainey, N.E.; Moustapha, A.; Petit, P.X. Curcumin, a multifaceted hormetic agent, mediates an intricate crosstalk between mitochondrial turnover, autophagy, and apoptosis. Oxid. Med. Cell Longev. 2020. [CrossRef] [PubMed]

71. Guo, J.; Cao, X.; Hu, X.; Li, S.; Wang, J. The anti-apoptotic, antioxidant and anti-inflammatory effects of curcumin on acrylamide-induced neurotoxicity in rats. BMC Pharm. Toxicol. 2020, 21, 62. [CrossRef]

72. Liu, H.; Mao, Y.; Xia, B.; Long, C.; Kuang, X.; Huang, H.; Ning, J.; Ma, X.; Zhang, H.; Wang, R.; et al. Curcumin Inhibits Proliferation and Epithelial-Mesenchymal Transition in Lens Epithelial Cells through Multiple Pathways. BioMed. Res. Int. 2020, 6061894. [CrossRef]

73. Chen, L.; Zhan, C.Z.; Wang, T.; You, H.; Yao, R. Curcumin inhibits the proliferation, migration, invasion, and apoptosis of diffuse large B-cell lymphoma cell line by regulating MiR-21/VHL axis. Yonsei Med. J. 2020, 61, 20-29. [CrossRef]

74. Ma, C.; Zhuang, Z.; Su, Q.; He, J.; Li, H. Curcumin has anti-proliferative and pro-apoptotic effects on tongue cancer in vitro: A study with bioinformatics analysis and in vitro experiments. Drug Des. Devel. Ther. 2020, 14, 509-518. [CrossRef]

75. Muangnoi, C.; Ratnatilaka Na Bhuket, P.; Jithavech, P.; Supasena, W.; Paraoan, L.; Patumraj, S.; Rojsitthisak, P. Curcumin diethyl disuccinate, a prodrug of curcumin, enhances anti-proliferative effect of curcumin against HepG2 cells via apoptosis induction. Sci. Rep. 2019, 9, 11718. [CrossRef]

76. World Cancer Report: Cancer Research for Cancer Prevention. In World Cancer Reports; License: CC BY-NC-ND 3.0 IGO; Wild, C.P.; Weiderpass, E.; Stewart, B.W. (Eds.) International Agency for Research on Cancer: Lyon, France, 2020; pp. 355-358. ISBN 13-978-92-832-0447-3. Available online: http://publications. iarc.fr/586 (accessed on 1 September 2020).

77. World Health Organization. Hepatitis, B. Available online: https://www.who.int/news-room/fact-sheets/ detail/hepatitis-b (accessed on 15 September 2020).

78. Cicalese, L.; Talavera, F.; Geibel, J.; Cagir, B.; Axelrod, D.A.; van Leeuwen, D.J. Hepatocellular Carcinoma. Available online: https://emedicine.medscape.com/article/197319-overview (accessed on 10 August 2020).

79. Colombo, M.; Lleo, A. The impact of antiviral therapy on hepatocellular carcinoma epidemiology. Hepatic. Oncol. 2018, 5, HEP03. [CrossRef]

80. Bray, F.; Ferlay, J.; Soerjomataram, I.; Siegel, L.R.; Torre, A.L.; Jemal, A. Global cancer statistics 2018: GLOBOCAN estimates of incidence and mortality worldwide for 36 cancers in 185 countries. CA Cancer J. Clin. 2018, 68, 394-424. [CrossRef]

81. Fourati, S.; Pawlotsky, J.M. Recent advances in understanding and diagnosing hepatitis B virus infection. F1000Research 2016, 5, F1000. [CrossRef] [PubMed]

82. Kim, D.H.; Kang, H.S.; Kim, K.H. Roles of hepatocyte nuclear factors in hepatitis B virus infection. World J. Gastroenterol. 2016, 22, 7017-7029. [CrossRef] [PubMed]

83. Chen, C.J. Global elimination of viral hepatitis and hepatocellular carcinoma: Opportunities and challenges. Gut 2018, 67, 595-598. [CrossRef] [PubMed]

84. D'Agnano, I.; Berardi, A.C. Extracellular Vesicles, A possible theranostic platform strategy for hepatocellular carcinoma-An overview. Cancers 2020, 12, 261. [CrossRef] [PubMed]

85. O’Hara, G.A.; McNaughton, A.L.; Maponga, T.; Jooste, P.; Ocama, P.; Chilengi, R.; Mokaya, J.; Liyayi, M.I.; Wachira, T.; Gikungi, D.M.; et al. Hepatitis B virus infection as a neglected tropical disease. PLoS Negl. Trop. Dis. 2017, 11, e0005842. [CrossRef] 
86. Dimri, M.; Satyanarayana, A. Molecular signaling pathways and therapeutic targets in hepatocellular carcinoma. Cancers 2020, 12, 491. [CrossRef]

87. Mantovani, N.; Cicero, M.; Santana, L.C.; Silveira, C.; do Carmo, E.P.; Abrão, P.R.; Diaz, R.S.; Caseiro, M.M.; Komninakis, S.V. Detection of lamivudine-resistant variants and mutations related to reduced antigenicity of HBsAg in individuals from the cities of Santos and São Paulo, Brazil. Virol. J. 2013, 10, 320. [CrossRef]

88. Pallier, C.; Castéra, L.; Soulier, A.; Hézode, C.; Nordmann, P.; Dhumeaux, D.; Pawlotsky, J.M. Dynamics of hepatitis B virus resistance to lamivudine. Virol. J. 2005, 80, 643-653. [CrossRef]

89. Liaw, Y.F.; Leung, N.W.; Chang, T.T.; Guan, R.; Tai, D.I.; Ng, K.Y.; Chien, R.N.; Dent, J.; Roman, L.; Edmundson, S.; et al. Effects of extended lamivudine therapy in Asian patients with chronic hepatitis B. Gastroenterology 2000, 119, 172-180. [CrossRef]

90. Lai, C.L.; Dienstag, J.; Schiff, E.; Leung, N.W.Y.; Atkins, M.; Hunt, C.; Brown, N.; Woessner, M.; Boehme, R.; Condreay, L. Prevalence and clinical correlates of YMDD variants during lamivudine therapy for patients with chronic hepatitis B. Clin. Infect. Dis. 2003, 36, 687-696. [CrossRef] [PubMed]

91. Tipples, G.A.; Ma, M.M.; Fischer, K.P.; Bain, V.G.; Kneteman, N.M.; Tyrrell, D.L. Mutation in HBV RNA-dependent DNA polymerase confers resistance to lamivudine in vivo. Hepatology 1996, 24, 714-717. [CrossRef] [PubMed]

92. Allen, M.I.; Deslauriers, M.; Andrews, W.C.; Tipples, G.A.; Walters, K.A.; Tyrrell, D.J.; Brown, N.; Condrea, L.D. Identification and characterization of mutations in hepatitis B virus resistant to lamivudine. Hepatology 1998, 27, 1670-1677. [CrossRef] [PubMed]

93. Bozdayi, A.M.; Uzunalimoğlu, Ö.; Türkyilmaz, A.R.; Aslan, N.; Sezgin, O.; Sahin, T.; Bozdayi, G.; Çinar, K.; Pai, S.B.; Pai, R. YSDD: A novel mutation in HBV DNA polymerase confers clinical resistance to lamivudine. J. Viral Hepat. 2003, 10, 256-265. [CrossRef]

94. Niesters, H.G.; De Man, R.A.; Pas, S.D.; Fries, E.; Osterhaus, A.D.M.E. Identification of a new variant in the YMDD motif of the hepatitis B virus polymerase gene selected during lamivudine therapy. J. Med. Microbiol. 2002, 51, 695-699. [CrossRef]

95. León, P.; Pozo, F.; Echevarría, M.J. Detection of hepatitis B virus variants resistant to lamivudine and famciclovir among randomly selected chronic carriers from Spain. Enferm. Infecc. Microbiol. Clin. 2004, 22, 133-137. [CrossRef]

96. Li, W.; Guo, Y.; Zhang, C.; Wu, R.; Yang, A.Y.; Gaspar, J.; Kong, A.N.T. Dietary phytochemicals and cancer chemoprevention: A perspective on oxidative stress, inflammation, and epigenetics. Chem. Res. Toxicol. 2016, 29, 2071-2095. [CrossRef]

97. Kotecha, R.; Takami, A.; Espinoza, J.L. Dietary phytochemicals and cancer chemoprevention: A review of the clinical evidence. Oncotarget 2016, 7, 52517-52529. [CrossRef]

98. Wang, D.; Veena, M.S.; Stevenson, K.; Tang, C.; Ho, B.; Suh, J.D.; Duarte, V.D.; Faull, K.F.; Mehta, K.; Srivatsan, E.S.; et al. Liposome-encapsulated curcumin suppresses growth of head and neck squamous cell carcinoma in vitro and in xenografts through the inhibition of nuclear factor $\kappa \mathrm{B}$ by an AKT-independent pathway. Clin. Cancer Res. 2008, 14, 6228-6236. [CrossRef]

99. Jobin, C.; Bradham, C.A.; Russo, M.P.; Juma, B.; Narula, A.S.; Brenner, D.A.; Sartor, R.B. Curcumin blocks cytokine-mediated NF-kB activation and proinflammatory gene expression by inhibiting inhibitory factor I-кB kinase activity. J. Immunol. 1999, 163, 3474-3483.

100. Plummer, S.M.; Holloway, K.A.; Manson, M.M.; Munks, R.J.L.; Kaptein, A.; Farrow, S.; Howells, L. Inhibition of cyclo-oxygenase 2 expression in colon cells by the chemopreventive agent curcumin involves inhibition of NF-kB activation via the NIK/IKK signalling complex. Oncogene 1999, 18, 6013-6020. [CrossRef] [PubMed]

101. Maiti, P.; Dunbar, G.L. Use of curcumin, a natural polyphenol for targeting molecular pathways in treating age-related neurodegenerative diseases. Int. J. Mol. Sci. 2018, 19, 1637. [CrossRef] [PubMed]

102. Biswas, S.K.; McClure, D.; Jimenez, L.A.; Megson, I.L.; Rahman, I. Curcumin induces glutathione biosynthesis and inhibits NF-kappaB activation and interleukin-8 release in alveolar epithelial cells: Mechanism of free radical scavenging activity. Antioxid. Redox Signal 2005, 7, 32-41. [CrossRef] [PubMed]

103. Moghadamtousi, S.Z.; Kadir, H.A.; Hassandarvish, P.; Tajik, H.; Abubakar, S.; Zandi, K. A review on antibacterial, antiviral, and antifungal activity of curcumin. BioMed. Res. Int. 2014, 186864. [CrossRef]

104. Shah, C.P.; Kharkar, P.S. Inosine 5'-monophosphate dehydrogenase inhibitors as antimicrobial agents: Recent progress and future perspectives. Future Med. Chem. 2015, 7, 1415-1429. [CrossRef] [PubMed] 
105. Kim, H.J.; Yoo, H.S.; Kim, C.J.; Park, C.S.; Choi, M.S.; Kim, M.; Choi, H.; Min, J.S.; Kim, Y.S.; Yoon, S.W.; et al. Antiviral effect of curcuma longa linn extract against hepatitis B virus replication. J. Ethnopharmacol. 2009, 124, 189-196. [CrossRef] [PubMed]

106. Tan, A.; Yeh, S.H.; Liu, C.J.; Cheung, C.; Chen, P.J. Viral hepatocarcinogenesis: From infection to cancer. Liver Int. 2008, 28, 175-188. [CrossRef]

107. Levrero, M.; Zucman-Rossi, J. Mechanisms of HBV-induced hepatocellular carcinoma. J. Hepatol. 2016, 64, S84-S101. [CrossRef]

108. Geng, M.; Xin, X.; Bi, L.Q.; Zhou, L.T.; Liu, X.H. Molecular mechanism of hepatitis B virus X protein function in hepatocarcinogenesis. World J. Gastroenterol. 2015, 21, 10732-10738. [CrossRef]

109. Teng, C.F.; Wu, H.C.; Shyu, W.C.; Jeng, L.B.; Su, I.J. Pre-S2 Mutant-induced mammalian target of rapamycin signal pathways as potential therapeutic targets for hepatitis B virus-associated hepatocellular carcinoma. Cell Transpl. 2017, 26, 429-438. [CrossRef]

110. Menon, V.P.; Sudheer, A.R. Antioxidant and anti-inflammatory properties of curcumin. Adv. Exp. Med. Biol. 2007, 595, 105-125. [PubMed]

111. He, Y.; Yue, Y.; Zheng, X.; Zhang, K.; Chen, S.; Du, Z. Curcumin, inflammation, and chronic diseases: How are they linked? Molecules 2015, 20, 9183-9213. [CrossRef] [PubMed]

112. Hong, J.; Bose, M.; Ju, J.; Ryu, J.H.; Chen, X.; Sang, S.; Lee, M.J.; Yang, C.S. Modulation of arachidonic acid metabolism by curcumin and related beta-diketone derivatives: Effects on cytosolic phospholipase $\mathrm{A}(2)$, cyclooxygenases and 5-lipoxygenase. Carcinogenesis 2004, 25, 1671-1679. [CrossRef] [PubMed]

113. Mazidi, M.; Karimi, E.; Meydani, M.; Ghayour-Mobarhan, M.; Ferns, G.A. Potential effects of curcumin on peroxisome proliferator-activated receptor-gamma in vitro and in vivo. World J. Methodol. 2016, 6, 112-117. [CrossRef] [PubMed]

114. Kim, J.H.; Song, J.; Park, K.W. The multifaceted factor peroxisome proliferator-activated receptor gamma (PPARgamma) in metabolism, immunity, and cancer. Arch. Pharm. Res. 2015, 38, 302-312. [CrossRef]

115. Wang, L.H.; Yang, X.Y.; Zhang, X.; Farrar, W.L. Inhibition of adhesive interaction between multiple myeloma and bone marrow stromal cells by PPARgamma cross talk with NF-kappaB and C/EBP. Blood 2007, 110, 4373-4384. [CrossRef]

116. Hatcher, H.; Planalp, R.; Cho, J.; Torti, F.M.; Torti, S.V. Curcumin: From ancient medicine to current clinical trials. Cell Mol. Life Sci. 2008, 65, 1631-1652. [CrossRef]

117. Johnson, S.M.; Gulhati, P.; Arrieta, I.; Wang, X.; Uchida, T.; Gao, T.; Evers, B.M. Curcumin inhibits proliferation of colorectal carcinoma by modulating Akt/mTOR signaling. Anticancer Res. 2009, 29, 3185-3190.

118. Saxton, R.A.; Sabatini, D.M. mTOR signaling in growth, metabolism, and disease. Cell 2017, 168, 960-976. [CrossRef]

119. Mohandas, K.M.; Desai, D.C. Epidemiology of digestive tract cancers in India. V. Large and small bowel. Indian J. Gastroenterol. 1999, 18, 118-121.

120. Shao, S.; Duan, W.; Xu, Q.; Li, X.; Han, L.; Li, W.; Zhang, D.; Wang, Z.; Lei, J. Curcumin suppresses hepatic stellate cell-induced hepatocarcinoma angiogenesis and invasion through downregulating CTGF. Oxidative Med. Cell. Longev. 2019, 8148510. [CrossRef] [PubMed]

121. Nasr, M.; Selima, E.; Hamed, O.; Kazem, A. Targeting different angiogenic pathways with combination of curcumin, leflunomide and perindopril inhibits diethylnitrosamine-induced hepatocellular carcinoma in mice. Eur. J. Pharm. 2014, 723, 267-275. [CrossRef]

122. Nassal, M. HBV cccDNA: Viral persistence reservoir and key obstacle for a cure of chronic hepatitis B. Gut 2015, 64, 1972-1984. [CrossRef]

123. Taranta, A.; Tien, S.B.; Zacher, B.J.; Rogalska-Taranta, M.; Manns, M.P.; Bock, C.T.; Wursthorn, K. Hepatitis $B$ virus DNA quantification with the three-in-one (3io) method allows accurate single-step differentiation of total HBV DNA and cccDNA in biopsy-size liver samples. J. Clin. Virol. 2014, 60, 354-360. [CrossRef] [PubMed]

124. You, C.R.; Lee, S.W.; Jang, J.W.; Yoon, S.K. Update on hepatitis B virus infection. World J. Gastroenterol. 2014, 20, 13293-13305. [CrossRef] [PubMed]

125. Cradick, T.J.; Keck, K.; Bradshaw, S.; Jamieson, A.C.; McCaffrey, A.P. Zinc-finger nucleases as a novel therapeutic strategy for targeting hepatitis B virus DNAs. Mol. Ther. 2010, 18, 947-954. [CrossRef] 
126. Chen, J.; Zhang, W.; Lin, J.; Wang, F.; Wu, M.; Chen, C.; Zheng, Y.; Peng, X.; Li, J.; Yuan, Z. An efficient antiviral strategy for targeting hepatitis $\mathrm{B}$ virus genome using transcription activator-like effector nucleases. Mol. Ther. 2014, 22, 303-311. [CrossRef]

127. Lin, S.R.; Yang, H.C.; Kuo, Y.T.; Liu, C.J.; Yang, T.Y.; Sung, K.C.; Lin, Y.Y.; Wang, H.Y.; Wang, C.C.; Shen, Y.C.; et al. The CRISPR/Cas9 system facilitates clearance of the intrahepatic HBV templates in vivo. Mol. Ther. Nucleic Acids 2014, 3, e186. [CrossRef]

128. Seeger, C.; Sohn, J.A. Targeting hepatitis B virus with CRISPR/Cas9. Mol. Ther. Nucleic Acids 2014, 3 , e216. [CrossRef]

129. Ramanan, V.; Shlomai, A.; Cox, D.B.; Schwartz, R.E.; Michailidis, E.; Bhatta, A.; Scott, D.A.; Zhang, F.; Rice, C.M.; Bhatia, S.N. CRISPR/Cas9 cleavage of viral DNA efficiently suppresses hepatitis B virus. Sci. Rep. 2015, 5, 10833. [CrossRef]

130. Zhu, X.; Li, Q.; Chang, R.; Yang, D.; Song, Z.; Guo, Q.; Huang, C. Curcumin alleviates neuropathic pain by inhibiting $\mathrm{p} 300 / \mathrm{CBP}$ histone acetyltransferase activity-regulated expression of BDNF and cox-2 in a rat model. PLoS ONE 2014, 9, e91303. [CrossRef] [PubMed]

131. Balasubramanyam, K.; Varier, R.A.; Altaf, M.; Swaminathan, V.; Siddappa, N.B.; Ranga, U.; Kundu, T.K. Curcumin, a novel p300/CREB-binding protein-specific inhibitor of acetyltransferase, represses the acetylation of histone/nonhistone proteins and histone acetyltransferase-dependent chromatin transcription. J. Biol. Chem. 2004, 279, 51163-51171. [CrossRef] [PubMed]

132. Mughal, M.H. Turmeric polyphenols: A comprehensive review. Integr. Food Nutr. Metab. 2019, 6. [CrossRef]

133. Weber, M.; Weber, R.; Junggebauer, M. Intravenous laser blood irradiation-Introduction of a new therapy. Chapter 5. In Medical Low-Level Laser Therapy-Foundations and Clinical Applications-Research Book, 2nd ed.; ISLA-International Society for Medical Laser Applications: Beverungen, Germany, 2015; pp. 279-297. ISBN 978-3-00-050017-6.

134. Giordano, A.; Tommonaro, G. Curcumin and cancer. Nutrients 2019, 11, 2376. [CrossRef]

135. Raab, O. Uber die wirkung fluoreszierender stoffe auf infusorien. Ztg. Biol. 1900, 39, 524-526.

136. Dolmans, D.E.; Fukumura, D.; Jain, R.K. Photodynamic therapy for cancer. Nat. Rev. Cancer 2003, 3, 380-387. [CrossRef]

137. All Nobel Prizes in Physiology or Medicine. The Nobel Prize in Physiology or Medicine. 1903. Available online: https://www.nobelprize.org/prizes/lists/all-nobel-laureates-in-physiology-or-medicine/ (accessed on 5 September 2020).

138. Von Tappeiner, H.; Jodlbauer, A. Die Sensiblilisierende Wirkung Fluoreszierender Substanzer Gesammte Untersuchungen uber die Photodynamische Erscheinerung; F.C.W. Vogel: Leipzig, Gremay, 1907.

139. Abrahamse, H.; Hamblin, M.R. New photosensitizers for photodynamic therapy. Biochem. J. 2016, 473, 347-364. [CrossRef]

140. Remembering Thomas Dougherty, PhD-Developer of Modern Cancer Therapy and Father of Photodynamic Therapy. Available online: https://www.internationalphotodynamic.com/new-blog/2018/11/16/rememberingthomas-dougherty-phd-developer-of-modern-cancer-therapy-and-father-of-photodynamic-therapy (accessed on 5 September 2020).

141. Agostinis, P.; Berg, K.; Cengel, K.A.; Foster, T.H.; Girotti, A.W.; Gollnick, S.O.; Hahn, S.M.; Hamblin, M.R.; Juzeniene, A.; Kessel, D.; et al. Photodynamic therapy of cancer: An update. CA Cancer J. Clin. 2011, 61, 250-281. [CrossRef]

142. Van Straten, D.; Mashayekhi, V.; De Bruijn, H.S.; Oliveira, S.; Robinson, D.J. Oncologic Photodynamic therapy: Basic principles, current clinical status and future directions. Cancers 2017, 9, 19. [CrossRef]

143. Maeding, N.; Verwanger, T.; Krammer, B. Boosting tumor-specific immunity using PDT. Cancers 2016, 8, 91. [CrossRef]

144. Sivasubramanian, M.; Chuang, Y.C.; Lo, L.-W. Evolution of nanoparticle-mediated photodynamic therapy: From superficial to deep-seated cancers. Molecules 2019, 24, 520. [CrossRef] [PubMed]

145. Getting Photodynamic Therapy. Available online: https://www.cancer.org/treatment/treatments-and-sideeffects/treatment-types/radiation/photodynamic-therapy.html (accessed on 6 September 2020).

146. Shafirstein, G.; Bellnier, D.; Oakley, E.; Hamilton, S.; Potasek, M.; Beeson, K.; Parilov, E. Interstitial photodynamic therapy-A focused review. Cancers 2017, 9, 12. [CrossRef] [PubMed]

147. Reddy, R.M.; Kakarala, M.; Wicha, M.S. Clinical Trial Design for testing the stem cell model for the prevention and treatment of cancer. Cancers 2011, 3, 2696-2708. [CrossRef] [PubMed] 
148. Wiehe, A.; O’Brien, J.M.; Senge, M.O. Trends and targets in antiviral phototherapy. Photochem. Photobiol. Sci. 2019, 18, 2565-2612. [CrossRef] [PubMed]

149. Enwemeka, C.S.; Bumah, V.V.; Masson-Meyers, D.S. Light as a potential treatment for pandemic coronavirus infections: A perspective. J. Photochem. Photobiol. B 2020, 207, 111891. [CrossRef] [PubMed]

150. Masson-Meyers, D.S.; Bumah, V.V.; Castel, C.; Castel, D.; Enwemeka, C.S. Pulsed 450 nm blue light significantly inactivates Propionibacterium acnes more than continuous wave blue light. J. Photochem. Photobiol. B 2020, 202, 111719. [CrossRef]

151. Biener, G.; Masson-Meyers, D.S.; Bumah, V.V.; Hussey, G.; Stoneman, M.R.; Enwemeka, C.S.; Raicu, V. Blue/violet laser inactivates methicillin-resistant Staphylococcus aureus by altering its transmembrane potential. J. Photochem. Photobiol. B 2017, 170, 118-124. [CrossRef]

152. Bumah, V.V.; Aboualizadeh, E.; Masson-Meyers, D.; Eells, J.; Enwemeka, C.S.; Hirschmugl, C. Resistance of B-DNA to blue light induced damage in methicillin resistant Staphylococcus aureus. J. Photochem. Photobiol. B 2017, 167, 150-157. [CrossRef]

153. Pang, P.; Wang, N.; Wang, C.; Yao, Y.; Fu, X.; Yu, W.; Cai, R.; Yao, M. 460 nm visible light irradiation eradicates MRSA via inducing prophage activation. J. Photochem. Photobiol. B 2017, 166, 311-322.

154. Muller-Breitkreutz, K.; Mohr, H.; Briviba, K.; Sies, H. Inactivation of viruses by chemically and photchemically generated singlet molecular oxygen. J. Photochem. Photobiol. B 1995, 30, 63-70. [CrossRef]

155. Bachmann, B.; Knuver-Hopf, J.; Lambrecht, B.; Mohr, H. Target structures for HIV-1 inactivation by methylene blue and light. J. Med. Virol. 1995, 47, 172-178. [CrossRef]

156. Wagner, S.J. Virus inactivation in blood components by photoactive phenothiazine dyes. Transfus. Med. Rev. 2002, 16, 61-66. [CrossRef] [PubMed]

157. Richardson, T.B.; Porter, C.D. Inactivation of murine leukaemia virus by exposure to visible light. Virology 2005, 341, 321-329. [CrossRef]

158. Dairaku, I.; Han, Y.; Yanaka, N.; Kato, N. Inhibitory effect of curcumin on IMP dehydrogenase, the target for anticancer and antiviral chemotherapy agents. Biosci. Biotechnol. Biochem. 2010, 74, 185-187. [CrossRef] [PubMed]

159. Shafabakhsh, R.; Pourhanifeh, M.H.; Mirzaei, H.R.; Sahebkar, A.; Asemi, Z.; Mirzaei, H. Targeting regulatory T cells by curcumin: A potential for cancer immunotherapy. Pharm. Res. 2019, 147, 104353. [CrossRef] [PubMed]

160. Bose, S.; Panda, A.K.; Mukherjee, S.; Sa, G. Curcumin and tumor immune-editing: Resurrecting the immune system. Cell Div. 2015, 10, 6. [CrossRef] [PubMed]

161. Sadreddini, S.; Baradaran, B.; Aghebati-Maleki, A.; Sadreddini, S.; Shanehbandi, D.; Fotouhi, A.; Aghebati-Maleki, L. Immune checkpoint blockade opens a new way to cancer immunotherapy. J. Cell Physiol. 2019, 234, 8541-8549. [CrossRef]

162. Hanson, H.L.; Donermeyer, D.L.; Ikeda, H.; White, J.M.; Shankaran, V.; Old, L.J.; Shiku, H.; Schreiber, R.D.; Allen, P.M. Eradication of established tumors by CD8+ T cell adoptive immunotherapy. Immunity 2000, 13, 265-276. [CrossRef]

163. Kalams, S.A.; Walker, B.D. The critical need for CD4 help in maintaining effective cytotoxic T lymphocyte responses. J. Exp. Med. 1998, 188, 2199-2204. [CrossRef]

164. Randazzo, W.; Aznar, R.; Sánchez, G. Curcumin-Mediated Photodynamic Inactivation of Norovirus Surrogates. Food Env. Virol. 2016, 8, 244-250. [CrossRef]

165. Buzzá, H.H.; Fialho de Freitas, L.C.; Moriyama, L.T.; Teixeira Rosa, R.G.; Bagnato, V.S.; Kurachi, C. Vascular effects of photodynamic therapy with curcumin in a chorioallantoic membrane model. Int. J. Mol. Sci. 2019, 20, 1084. [CrossRef] [PubMed]

(C) 2020 by the authors. Licensee MDPI, Basel, Switzerland. This article is an open access article distributed under the terms and conditions of the Creative Commons Attribution (CC BY) license (http://creativecommons.org/licenses/by/4.0/). 